\title{
ELDER ABUSE WITHIN THE FAMILY ENVIRONMENT: A SYSTEMATIC REVIEW
}

\author{
María Gracia Carpena-Niño, PhD 1,2, , César Cuesta-García, PhD 1,2, Eduardo Lorenzo-Martín, OT 1, Laura Ramírez- \\ Peña, OT ${ }^{1}$, Beatriz Madroñero-Miguel, MsC ${ }^{1}$, Pedro Amalio Serrano-López-Terradas, MsC 1,2,3 \\ 1. Departamento de Terapia Ocupacional. Centro Superior de Estudios Universitarios La Salle. Universidad Autónoma de Madrid. 28023 Madrid (Spain) \\ 2. Occupational Thinks Research Group. Centro Superior de Estudios Universitarios La Salle. Universidad Autónoma de Madrid. 28023 Madrid (Spain) \\ 3. Unidad de Daño Cerebral, Hospital Beata María Ana, 28007 Madrid (Spain)
}

\section{Correspondence:}

María Gracia Carpena-Niño, $\mathrm{PhD}$ Departamento de Terapia Ocupacional. Centro Superior de Estudios Universitarios La Salle, Madrid, España Telephone: (+34) 619874813 E-mail: mgcarpena@lasallecampus.es

\section{Conflict of Interest:}

The authors declare that they have no conflicts of interest. This project has not been presented at any scientific event.

\section{Funding:}

The authors declare that they have not received funding/compensation for the development of this research.

DOI:

https://doi.org/10.37382/jomts.v3i1.466

\section{Receipt of Manuscript:}

1-June-2021

\section{Acceptance of the Manuscript:}

10-June-2021

Licensed under:

\begin{abstract}
Background: Fundamental freedoms and human rights should be inviolable throughout life, without prejudice, ensuring the individual's highest possible level of physical and mental health. However, mistreatment of the elderly remains a major public health problem in today's society. The main objective of this systematic review was to identify the variables that influence elder abuse. The secondary objectives were to identify the demographic characteristics of caregivers of older adults who reside in their homes; determine whether there was a kinship relationship between caregivers and older adults; identify the degree of functional dependence of older adults; and determine the prevailing types of abuse in the home environment.
\end{abstract}

Methods: We conducted a literature search according to Preferred Reporting Items for Systematic Reviews and Meta-Analyses standards on December 26 and 27, 2019 in the SCIELO, CUIDEN, CINAHL, PubMed and Google Scholar databases. The search process was conducted by two independent reviewers using the same methodology, and their discrepancies were resolved by consensus.

Results: A total of 46 cross-sectional studies and one case-control study were selected. The cross-sectional articles showed poor and fair methodological quality, whereas the case-control study presented good methodological quality. Limited evidence suggests that being abused is more often associated with being female, having a lower income, having cognitive or functional impairment, having mood disorders and having a first-degree relationship with the abuser. The qualitative analysis also showed conflicting evidence regarding the victims' educational level.

Conclusions: The results of this systematic review show that there are numerous risk factors that increase the prevalence of abuse. Further research and review studies are needed in this area.

Keywords: Abuse; Elderly; Family; Neglect; Substance-related disorder. 


\section{INTRODUCTION}

In recent decades, there has been an increase in longevity as a result of medical advances and better control of age-related morbidity and mortality. With a longer life expectancy, it is foreseeable that improved health care for the elderly population will lead to better health quality and functional capacity. This is not always the case, however, and this heterogeneous and vulnerable group often has very diverse care needs due to fragility, lack of autonomy and impaired capacity, leaving them at risk of mistreatment, abuse, and neglect (Segura, 2016). We lack a valid consensus definition as to what constitutes violence, mistreatment, and abuse toward the elderly, despite the existence of several psychological, sociological and ecological models focused on abuse (Tortosa, 2004). An individual's vulnerability in their own environment will determine their behavior and state of well-being. Symbiotically, an individual's habitual physical and social environments will also condition (positively or negatively) the state of their psycho-physical health throughout life (Beard et al., 2015). At any stage of life, an individual's fundamental freedoms and human rights must remain inviolable, without prejudice from external causes, either by a single or repeated act that might cause them harm, damage or suffering, or by the absence of an appropriate response to their injury (Organización Panamericana de la Salud, 2008; OMS, 2018).

Mistreatment of the elderly constitutes a major public health problem in today's society, entailing serious socioeconomic consequences and grave repercussions for mental and physical health (Beard et al., 2015; Naciones Unidas, 2020). Given that mistreatment is a more subtle type of violence, it can often remain hidden. It is estimated that 1 in 6 older adults have experienced some type of abuse in the past year (Nyamwanza, 2014), and yet only $20 \%$ of cases of elder abuse are considered to be reported. Studies analyzing the "suspicion of unconfirmed abuse" have indicated a $12 \%$ prevalence of such abuse in this age group (Generalitat de Catalunya, 2007).

For events to be classified as abuse, they must occur within the framework of an interpersonal relationship in which there is an expectation of trust, care, cohabitation or dependence, and the aggressor can be a family member, institutional staff (from the health field or social services), a hired caregiver, a neighbor, or even a friend (Marmolejo, 2008).

Elder abuse by family members dates back to antiquity, when abuse was considered a private matter not to be made public. Since the end of the 16th century, acts of family violence in Spain could be dealt with before the Seigniorial Courts of Justice. However, few texts with complaints about this type of event have been preserved. These texts describe vulnerable victims marked by feelings of shame, fear, guilt, concealment and resignation in the face of abuse (González, 2006). Centuries later, the devastating cognitive-behavioral impact of ongoing domestic abuse results in victims who manifest learned disability, helplessness, or hopelessness (Quirós, 2003). Although the mistreatment of older adults was first identified in developed countries, it was not until the 1970s that the term "elder abuse" was coined and when most of the existing research began (Bazo, 2001). Anecdotal facts and data from developing countries have shown that abuse is a universal phenomenon (Krug et al., 2003).

In 2019, 19.3\% of the Spanish population were aged 65 years or older $(9,057,193$ million people) (Pérez-Díaz et al., 2020). The number of cases related to abuse in the geriatric population has increased due to the aging of population, greater control over diseases, and various socio-cultural changes (Krug et al., 2003). However, only one out of every 24 cases of abuse is reported, according to the World Health Organization. It can therefore be deduced that elder abuse is still a private matter in many countries (OMS, 2020).

Elder abuse can be committed either by action or omission and can be intentional or unintentional. In all kinds of mistreatment against the elderly, older adults are unquestionably the victims of unnecessary suffering, injury or pain, loss or violation of their human rights, and deterioration of their quality of life (Saavedra et al., 2020). Changes in family relational models and social values and the development of resources aimed at protecting this age group have contributed to raising the awareness of the social conscience, although it is still insufficient (Estrada, 
2008). Guidelines, reports and statements from expert committees dealing with elder abuse emphasize the lack of the following: legal frameworks for the defense of older adults; the early diagnosis of physical, psychological, behavioral and economic indicators and neglect, cruelty and discrimination; specific social education; and the need for greater multisectoral participation (OMS, 2002; Moya-Bernal and BarberoGutiérrez, 2005; Marmolejo, 2008). To eradicate this crisis in public health, up-to-date knowledge on the real scope of abuse and its various types is essential, especially in parts of the world where data are scarce, such as South-East Asia, the Middle East and Africa (Krug et al., 2003; Moher et al., 2009).

The main objective of this systematic review was to identify the variables that influence elder abuse. The secondary objectives were to identify the demographic characteristics of the caregivers of older adults who reside in their homes; determine if there is a kinship relationship between caregivers and older adults; identify the degree of functional dependence of older adults; and determine the prevailing types of abuse in the home environment.

\section{METHODS}

\section{Study design}

The present systematic review of observational studies (cross-sectional and case-control designs) was conducted following a protocol divided into four phases and based on the standards of the Preferred Reporting Items for Systematic Reviews and MetaAnalyses statement (Moher et al., 2009).

\section{Study inclusion criteria}

The studies included in this systematic review met the following criteria: cross-sectional design, either cohort or case-control studies; analyzed abuse or mistreatment within the family environment; study population over 60 years of age; and published since 2000.

\section{Search strategy}

The following databases were employed for the systematic search of observational articles: SciELO (December 26, 2019), CINAHL (December 26, 2019),
CUIDEN (December 26, 2019), Cochrane (December 26, 2019), PubMed (December 27, 2019) and Google Scholar (December 26, 2019). The terms used for the search were derived from a combination of Medical Subject Headings (MeSH) terms ("aged", "family", "substance-related disorders") and non-MeSH terms ("elderly", "neglect", "abuse") through the use of different Boolean operators (AND/OR/NOT), as shown in Appendix 1. In the CUIDEN database, we employed the Spanish search terms for "mistreatment" and "elderly" ("maltrato", "anciano"). The time range (from 2000 to the present) and the removal of patents and citations were used as filters.

\section{Selection criteria and data extraction}

Two independent reviewers performed the first evaluation of the studies to assess their relevance to the present systematic review. The first analysis was performed using the information from each study's title, abstract, and keywords. If there was a lack of consensus or if the information provided by the abstract was insufficient, the full text was reviewed. During the second phase, the full texts were reviewed to verify that the selected studies met the inclusion criteria. A third reviewer acted as an expert mediator to reach a consensus when there were disagreements between the two reviewers. The data described in the results were extracted by means of a structured protocol that ensured the most relevant information from each study was obtained.

\section{Methodological quality assessment}

The methodological quality of the articles included in this review was assessed using the modified version of the Newcastle-Ottawa Quality Assessment Scale (NOS) (Deeks et al., 2003), which is an appropriate tool for assessing the quality of case-control, cohort and cross-sectional studies and has moderate inter-rater reliability (Hootman et al., 2011). The NOS assesses three criteria with a range of 0 to 4 stars: grade selection of participants; assessment of exposures, outcomes, and comparability; and control of confounding variables. The tallied stars provide four categories of study quality: poor, 0-3 stars; fair, 4-5 stars; good, 6-7 stars; and excellent, 8-9 stars (Wells et al., 2008). To analyze the methodological quality of 
the cross-sectional studies, we employed the NOS modifications proposed by Fingleton et al. (Fingleton et al., 2015). The tallied stars provide 3 categories of study quality: poor, $0-1$ out of 3 ; fair, 2 out of 3 ; and good, 3 out of 3 .

Two independent reviewers examined the methodological quality of the selected studies using the same methods. Disagreements between the reviewers were resolved by a consensus that included mediation by a third expert reviewer. The inter-rater reliability was determined using the Kappa coefficient, in which $\kappa>0.7$ indicated a high level of inter-rater agreement; $\kappa=0.5-0.7$ indicated a moderate level of agreement; and $\kappa<0.5$ indicated a low level of agreement (Cohen, 1960).

\section{Qualitative analysis}

For the qualitative analysis of the selected observational studies, we employed an adaptation of the classification criteria proposed by van Tulder et al. for randomized clinical trials (van Tulder et al., 2003). We categorized the results into five levels depending on the methodological quality: strong evidence, consistent among multiple high-quality casecontrol/cohort/cross-sectional studies (at least 3); moderate evidence, consistent findings from multiple low-quality case-control/cohort/cross-sectional studies and/or one high-quality case-control/cohort study; limited evidence, 1 low-quality case-control/cohort studies and/or at least 2 cross-sectional studies; conflicting evidence, inconsistent findings among multiple studies (case-control/cohort/cross-sectional studies); and no evidence, no casecontrol/cohort/cross-sectional studies reported.

\section{RESULTS}

A total of 46 cross-sectional studies (Ruiz Sanmartín et al., 2001; Kuniyoshi et al., 2003; Zimmelová, 2004; Heath et al., 2005; HernándezRamírez, 2005; Daskalopoulos, 2006; Manthorpe et al., 2007; Sánchez-Salgado, 2007; Gaiolo and Rodrigues, 2008; Rinsky and Malley-Morrinson, 2008; Roberto et al., 2008; Biggs et al., 2009; Acierno et al., 2010; Rodrigues et al., 2010; Ghodousi et al., 2011; Kissal and Beşer, 2011; Lai, 2011; Shimbo et al., 2011; Amstadter et al., 2011; Abdel Rahman and El Gaafary,
2012; Almeida-da-Silva et al., 2012; Chan et al., 2013; Edirisinghe et al., 2014; Alizadeh-Khoei et al., 2014; Martins-Gil et al., 2014; Park, 2014; Reis et al., 2014; Skirbekk and James, 2014; Wilson et al., 2014; de Paiva and Tavares, 2015; Gil et al., 2015; Smith, 2015; Tareque et al., 2015; Carmona-Torres et al., 2015; Morowatisharifabad et al., 2016; Sepúlveda-Carrillo et al., 2016; Evandrou et al., 2017; Farid, 2017; Leung et al., 2017; Lino et al., 2017; Özcan et al., 2017; Silva et al., 2018; Breckman et al., 2018; Curcio et al., 2019; Kołodziejczak et al., 2019; Arruda et al., 2019) and one case-control study (Friedman et al., 2011) were selected in the first phase of the analysis (Figure 1). In all articles, the following variables were analyzed: age (Ruiz Sanmartín et al., 2001; Kuniyoshi et al., 2003; Gaiolo and Rodrigues, 2008; Friedman et al., 2011; Ghodousi et al., 2011; Kissal and Beşer, 2011; Amstadter et al., 2011; Abdel Rahman and El Gaafary, 2012; Chan et al., 2013; Alizadeh-Khoei et al., 2014; Skirbekk and James, 2014; Edirisinghe et al., 2014; Gil et al., 2015; Carmona-Torres et al., 2015; de Paiva and Tavares, 2015; Morowatisharifabad et al., 2016; Sepúlveda-Carrillo et al., 2016; Leung et al., 2017; Silva et al., 2018; Breckman et al., 2018; Arruda et al., 2019; Curcio et al., 2019), sex (Ruiz Sanmartín et al., 2001; Kuniyoshi et al., 2003; Gaiolo and Rodrigues, 2008; Friedman et al., 2011; Ghodousi et al., 2011; Kissal and Beşer, 2011; Amstadter et al., 2011; Abdel Rahman and El Gaafary, 2012; Chan et al., 2013; Alizadeh-Khoei et al., 2014; Skirbekk and James, 2014; Edirisinghe et al., 2014; Gil et al., 2015; Tareque et al., 2015; Carmona-Torres et al., 2015; de Paiva and Tavares, 2015; Sepúlveda-Carrillo et al., 2016; Evandrou et al., 2017; Leung et al., 2017; Lino et al., 2017; Özcan et al., 2017; Silva et al., 2018; Breckman et al., 2018; Arruda et al., 2019; Curcio et al., 2019), marital status (Ruiz Sanmartín et al., 2001; Gaiolo and Rodrigues, 2008; Alizadeh-Khoei et al., 2014; Edirisinghe et al., 2014; Smith, 2015; Tareque et al., 2015; Carmona-Torres et al., 2015; de Paiva and Tavares, 2015; Gil et al., 2015; Sepúlveda-Carrillo et al., 2016; Morowatisharifabad et al., 2016; Leung et al., 2017; Silva et al., 2018; Breckman et al., 2018; Arruda et al., 2019), educational level (Ruiz Sanmartín et al., 2001; Ghodousi et al., 2011; Kissal and Beşer, 2011; Alizadeh-Khoei et al., 2014; Edirisinghe et al., 
2014; Tareque et al., 2015; Carmona-Torres et al., 2015; de Paiva and Tavares, 2015; Gil et al., 2015; Morowatisharifabad et al., 2016; Sepúlveda-Carrillo et al., 2016; Leung et al., 2017; Breckman et al., 2018; Arruda et al., 2019), cohabitation (Ruiz Sanmartín et al., 2001; Amstadter et al., 2011; Kissal and Beşer, 2011; Abdel Rahman and El Gaafary, 2012; AlizadehKhoei et al., 2014; Edirisinghe et al., 2014; Skirbekk and James, 2014; Özcan et al., 2017; Arruda et al., 2019), family relationship between victim and aggressor (Ruiz Sanmartín et al., 2001; Kuniyoshi et al., 2003; Zimmelová, 2004; Sánchez-Salgado, 2007; Gaiolo and Rodrigues, 2008; Friedman et al., 2011; Lai, 2011; Abdel Rahman and El Gaafary, 2012; Gil et al., 2015; Smith, 2015; Sepúlveda-Carrillo et al., 2016), existence of mood disorders (Heath et al., 2005; Lino et al., 2017; Breckman et al., 2018), cognitive impairment (Ruiz Sanmartín et al., 2001; Heath et al., 2005; Leung et al., 2017; Lino et al., 2017; Breckman et al., 2018), substance abuse (Friedman et al., 2011; Ghodousi et al., 2011; Lino et al., 2017), level of functional independence (Ruiz Sanmartín et al., 2001; Kissal and Beşer, 2011; Abdel Rahman and El Gaafary, 2012; de Paiva and Tavares, 2015; Breckman et al., 2018; Curcio et al., 2019), income level (Sánchez-Salgado, 2007; Ghodousi et al., 2011; Almeida-da-Silva et al., 2012; Alizadeh-Khoei et al., 2014; Gil et al., 2015; Tareque et al., 2015; Arruda et al., 2019), and type of abuse (Ruiz Sanmartín et al., 2001; Kuniyoshi et al., 2003; Zimmelová, 2004; Heath et al., 2005; Hernández-Ramírez, 2005; Daskalopoulos, 2006; Manthorpe et al., 2007; Sánchez-Salgado, 2007; Gaiolo and Rodrigues, 2008; Rinsky and Malley-Morrinson, 2008; Roberto et al., 2008; Biggs et al., 2009; Acierno et al., 2010; Rodrigues et al., 2010; Friedman et al., 2011; Ghodousi et al., 2011; Kissal and Beşer, 2011; Lai, 2011; Amstadter et al., 2011; Shimbo et al., 2011; Abdel Rahman and El Gaafary, 2012; Chan et al., 2013; Edirisinghe et al., 2014; Alizadeh-Khoei et al., 2014; Martins-Gil et al., 2014; Park, 2014; Reis et al., 2014; Skirbekk and James, 2014; Wilson et al., 2014; de Paiva and Tavares, 2015; Gil et al., 2015; Smith, 2015; Tareque et al., 2015; Carmona-Torres et al., 2015; Morowatisharifabad et al., 2016; SepúlvedaCarrillo et al., 2016; Evandrou et al., 2017; Farid,
2017; Özcan et al., 2017; Silva et al., 2018; Kołodziejczak et al., 2019; Arruda et al., 2019; Curcio et al., 2019). Table 1 lists each study's sample characteristics, inclusion criteria, outcome measures, assessment measures and conclusions.

Figure 1. Flow chart of the items selected with the PRISMA method.

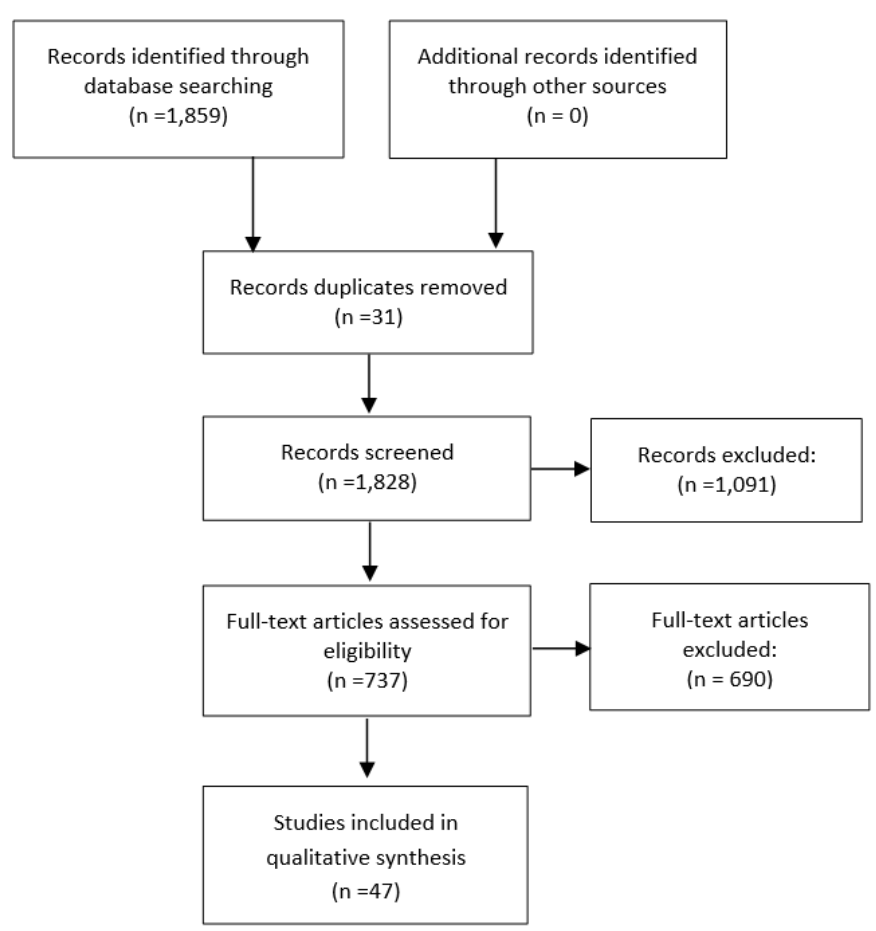

\section{Study population characteristics}

All studies were conducted on geriatric populations. A total of 89,315 participants aged 60 years and over were evaluated, and the mean age was 71.4 years. In 21 studies, the sample consisted predominantly of women. Only in 1 study did the number of men exceed the number of women (Acierno et al., 2010).

\section{Results of the methodological quality assessment}

Of the 47 articles included in the present systematic review, 46 were cross-sectional and one was casecontrol, with 37 of the cross-sectional articles showing poor methodological quality ( $1 / 3$ stars) (Ruiz Sanmartín et al., 2001; Kuniyoshi et al., 2003; Zimmelová, 2004; Hernández-Ramírez, 2005; Daskalopoulos, 2006; Rinsky and Malley-Morrinson, 2008; Roberto et al., 2008; Rodrigues et al., 2010; Ghodousi et al., 2011; Kissal and Beşer, 2011; Lai, 2011; Amstadter et al., 2011; Shimbo et al., 2011; Abdel Rahman and El Gaafary, 2012; Almeida-da- 


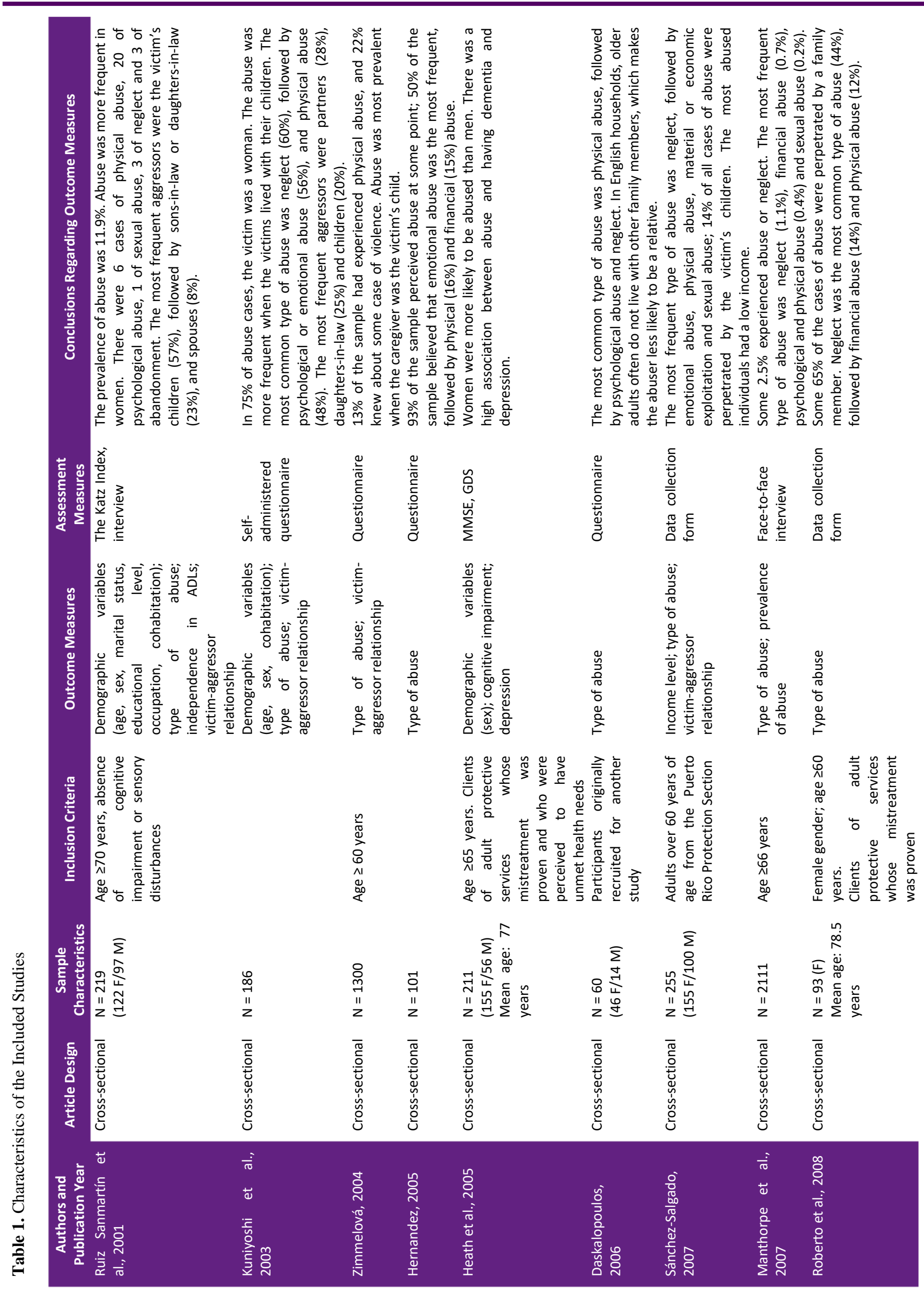



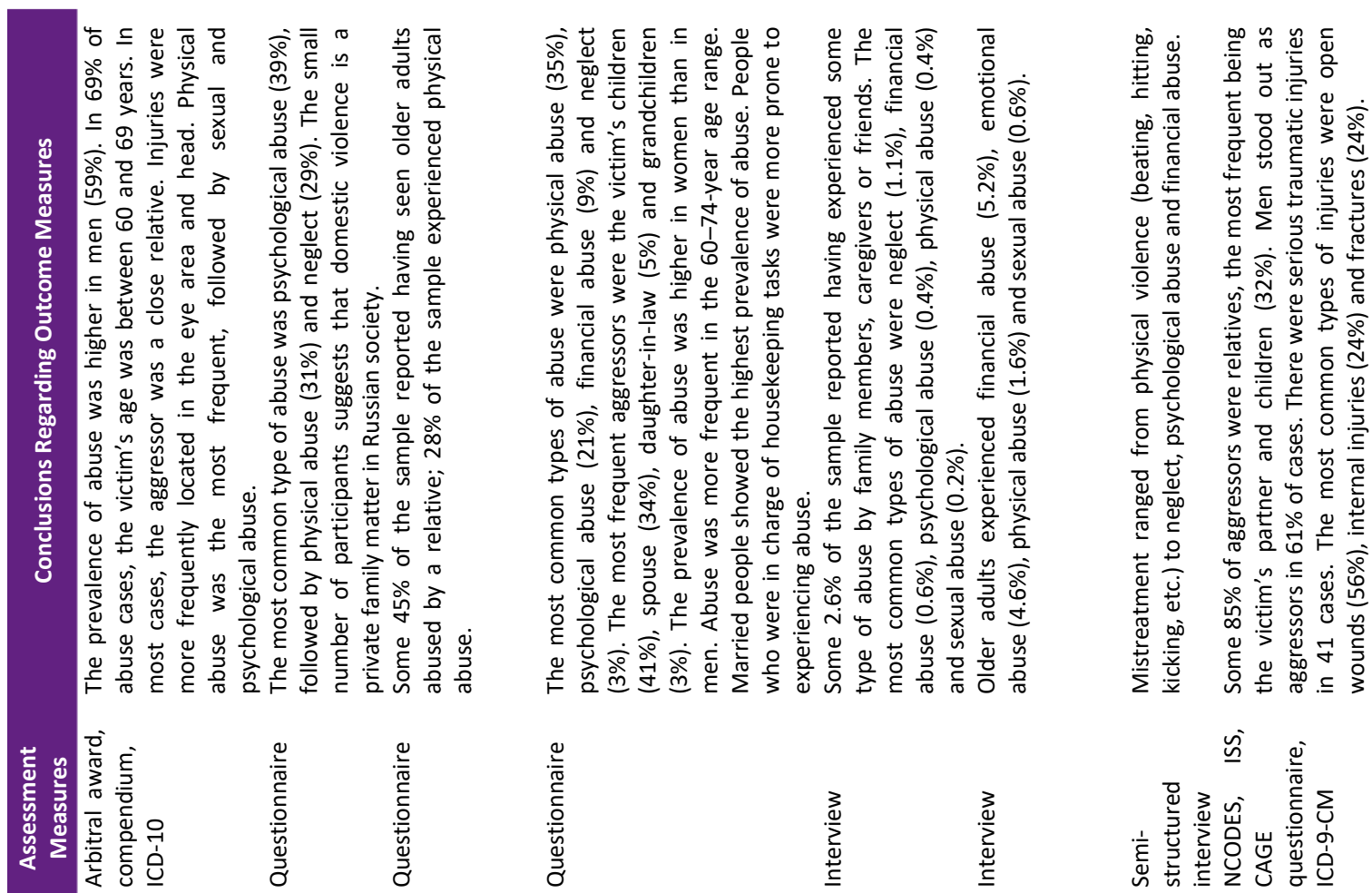

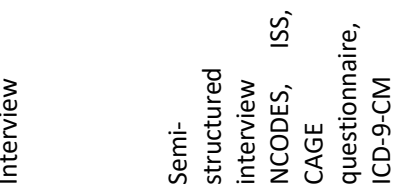
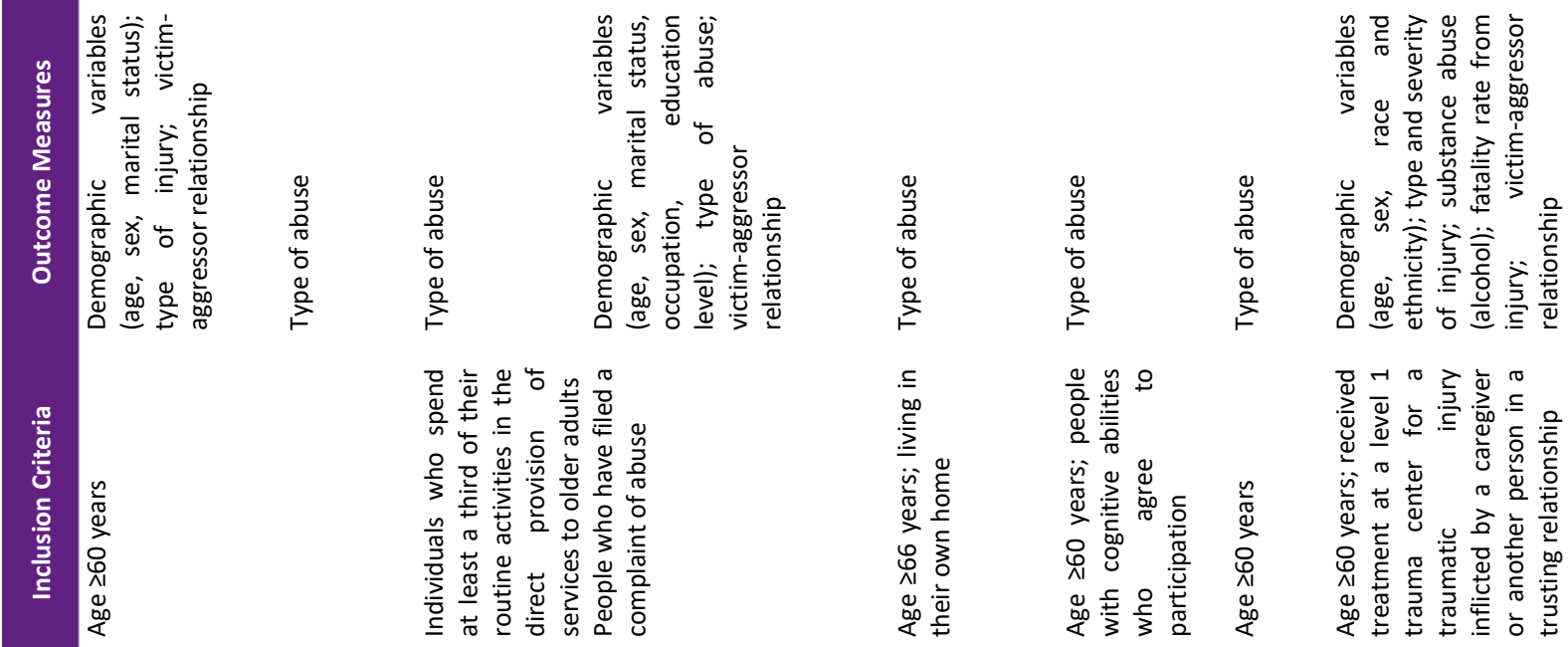

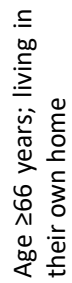
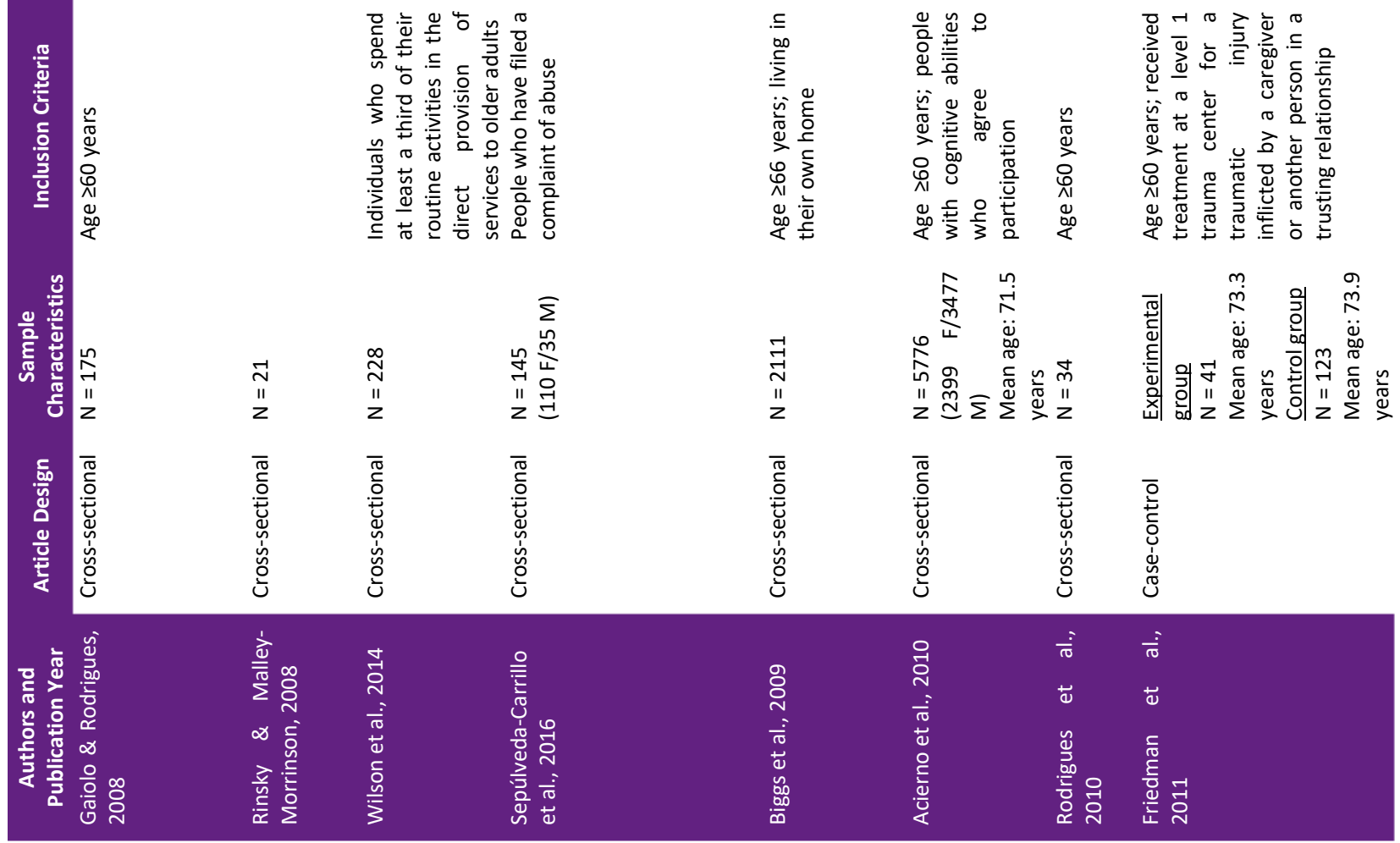


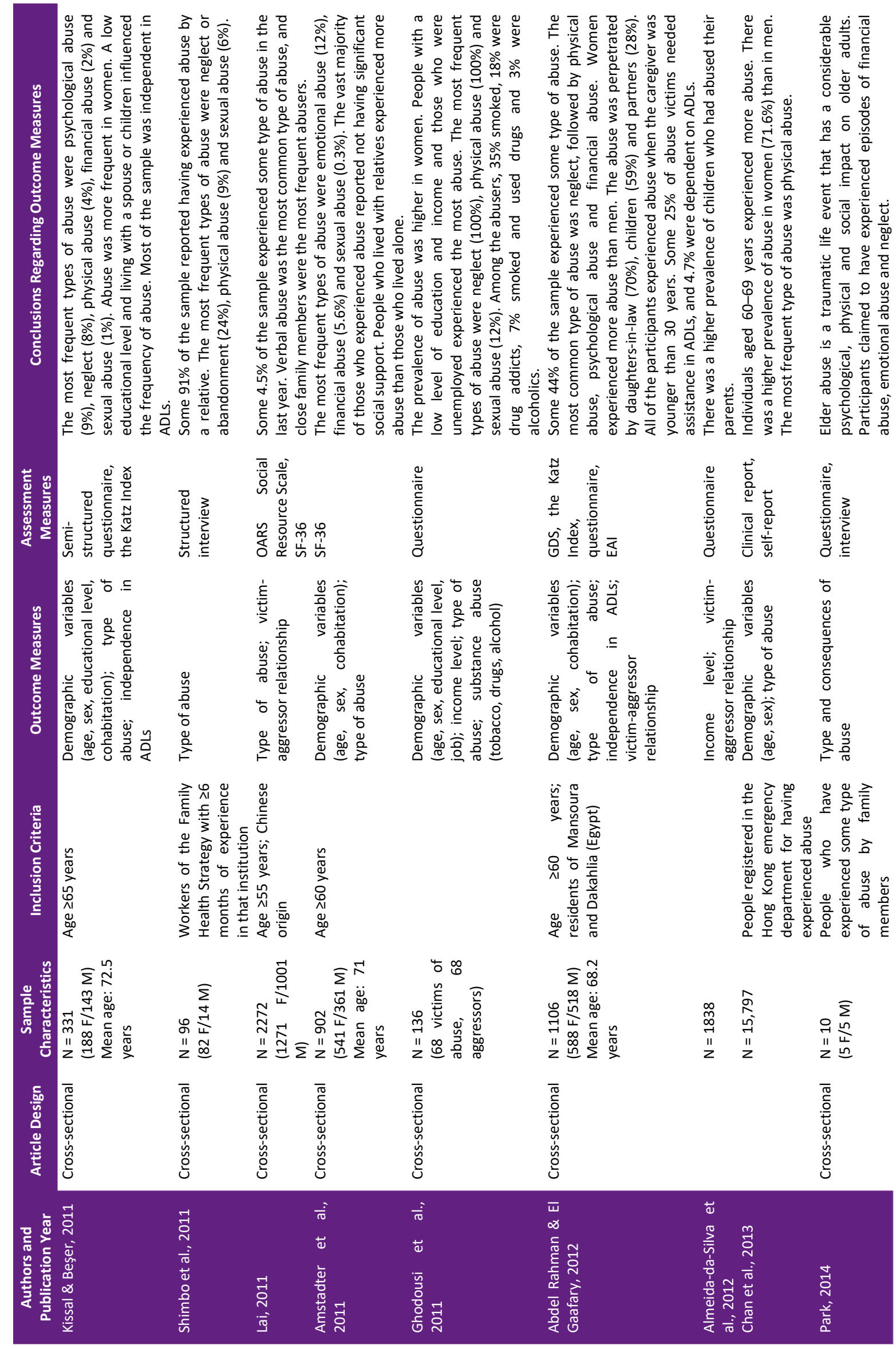




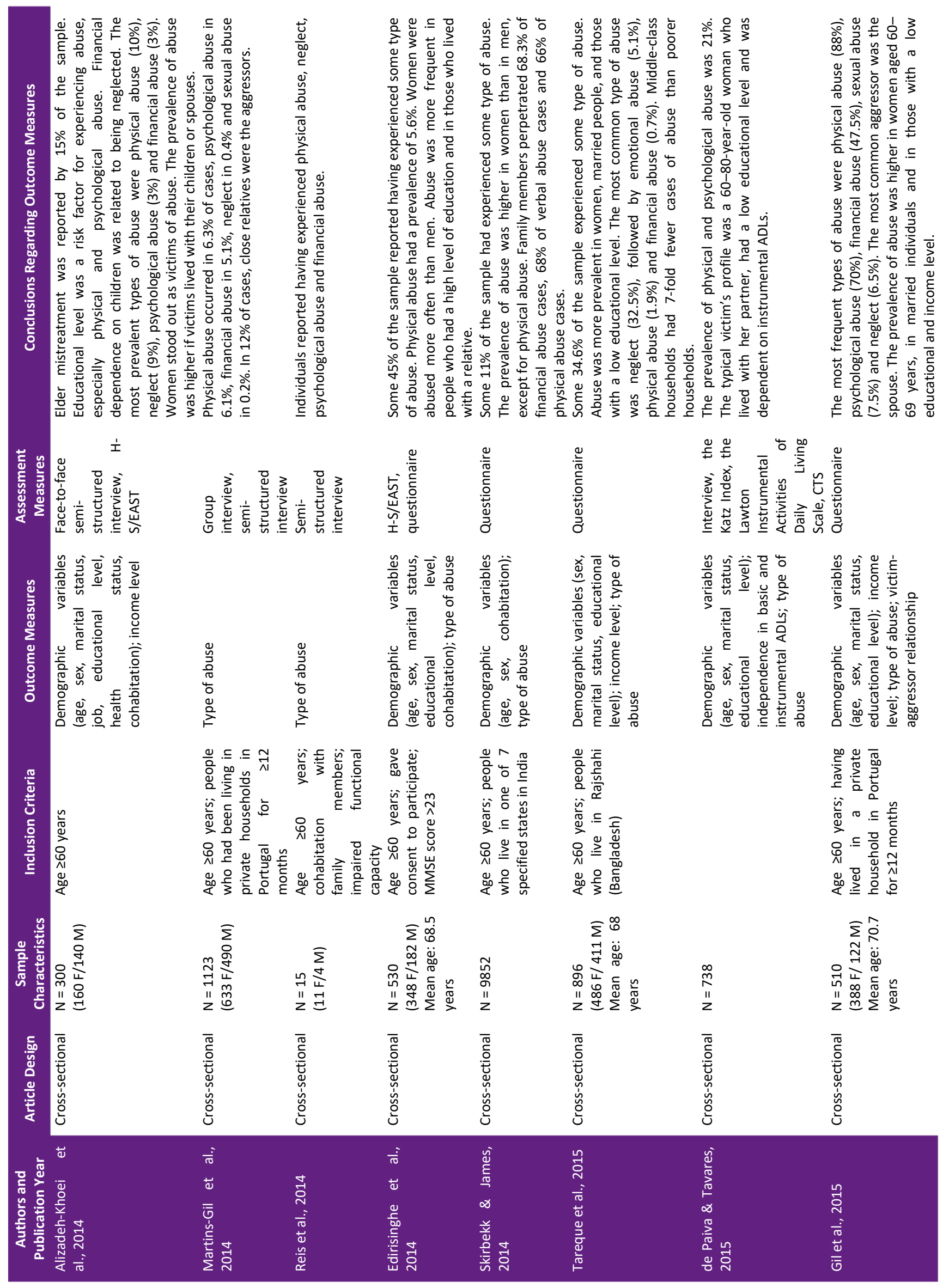



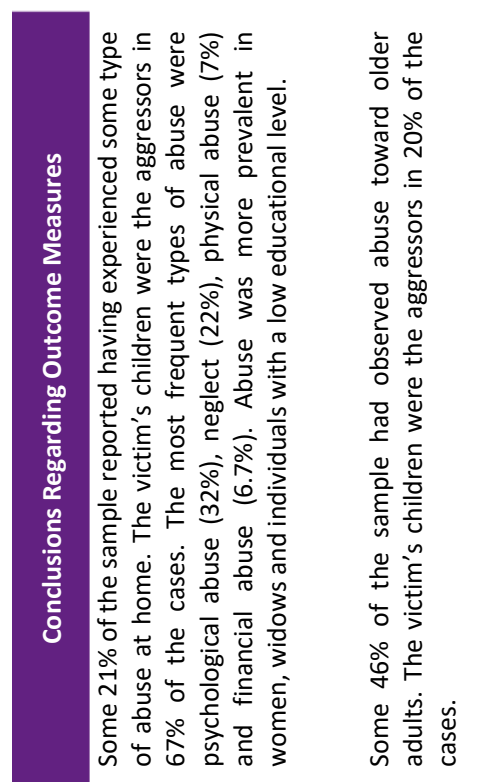

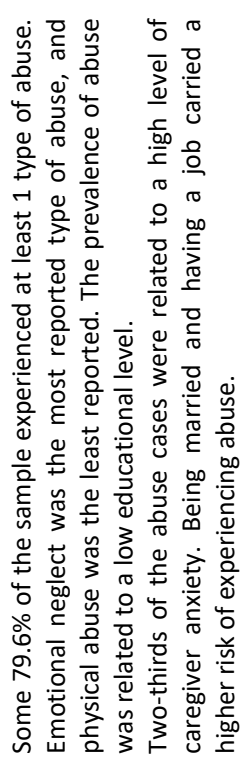
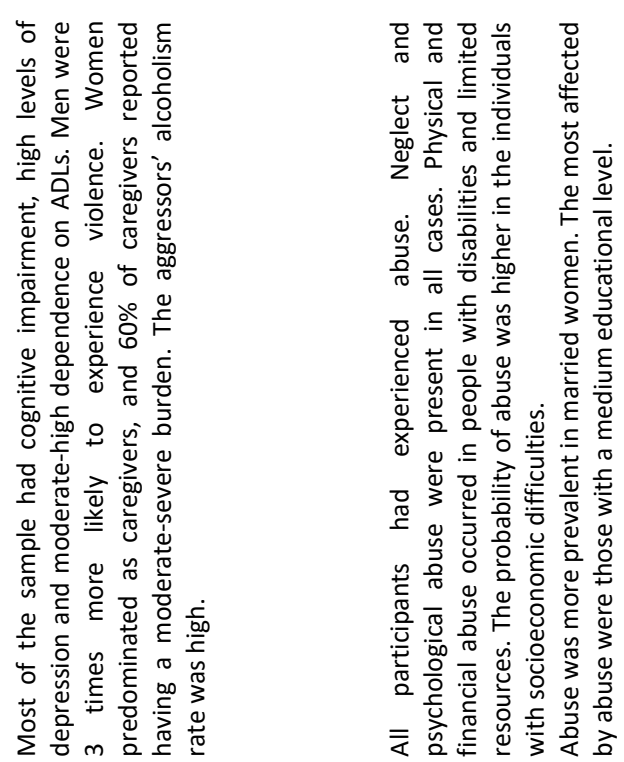

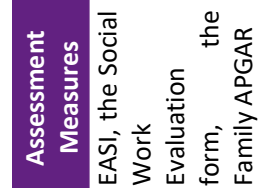

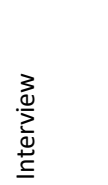

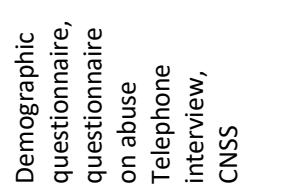

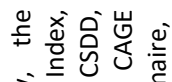

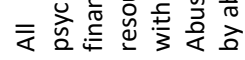

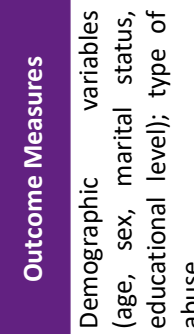
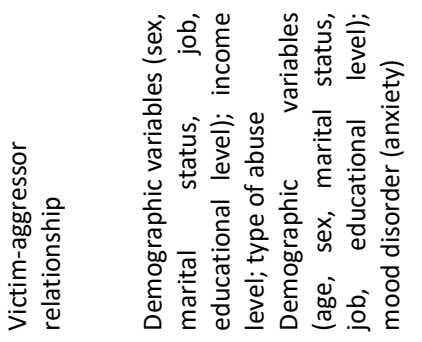

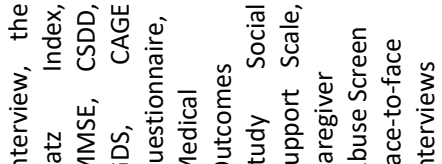

茓

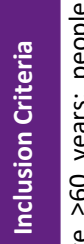

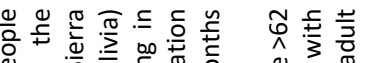

in

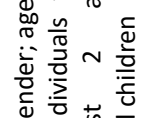

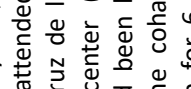

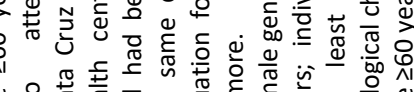

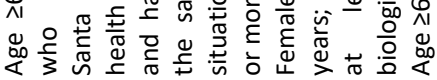

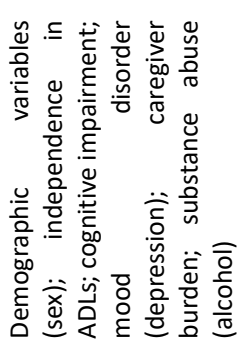

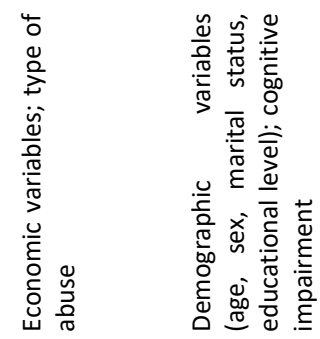

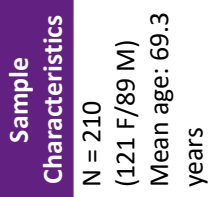

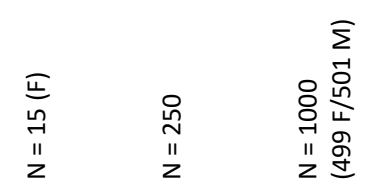

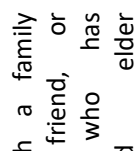

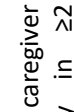

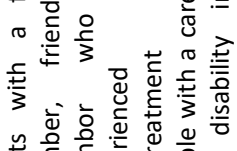

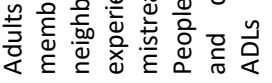

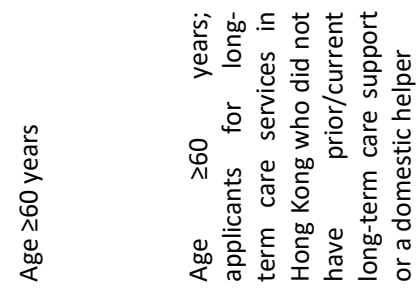

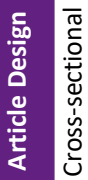

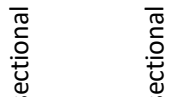

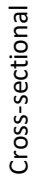

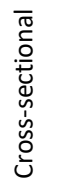

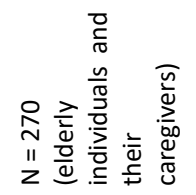

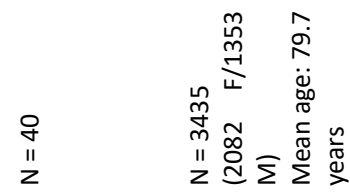
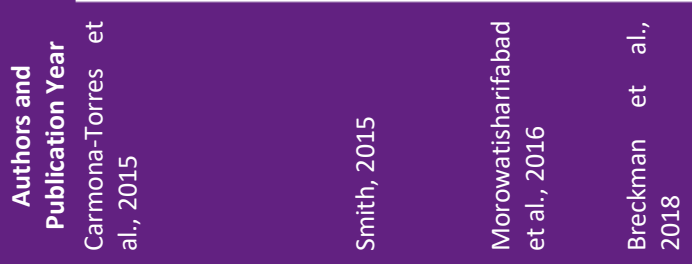

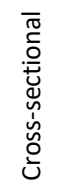

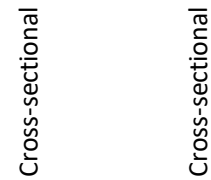

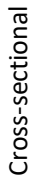

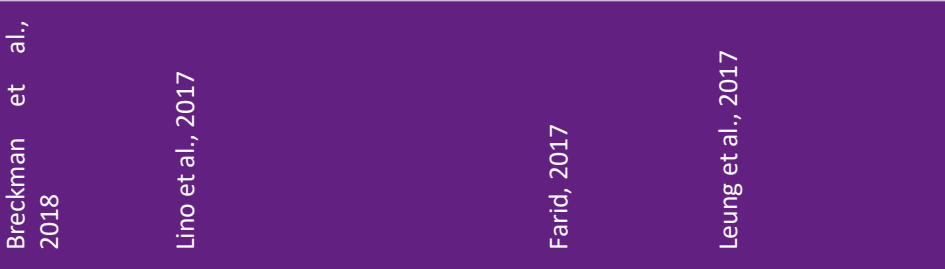




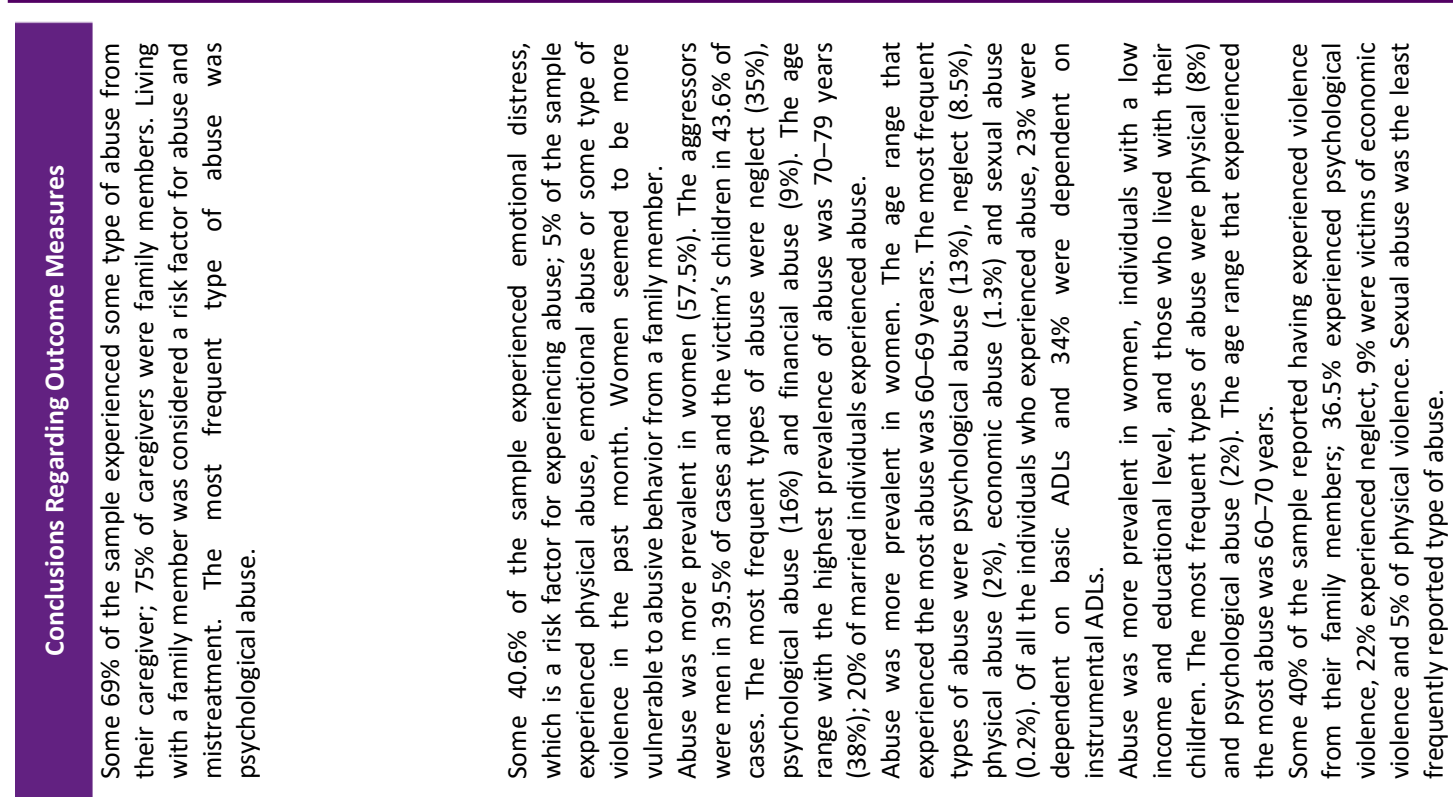

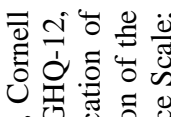

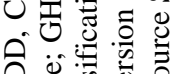

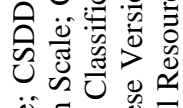
है.

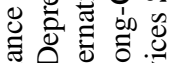

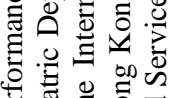

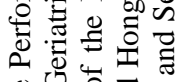
O

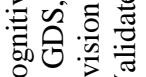
0 论 นึँ 政 至全造文

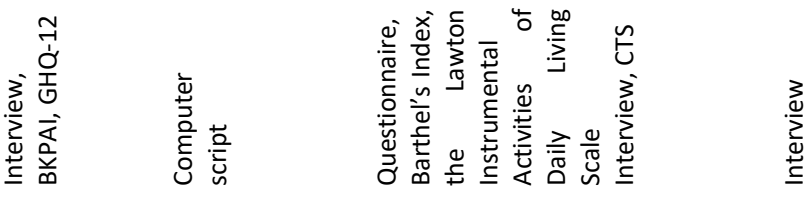

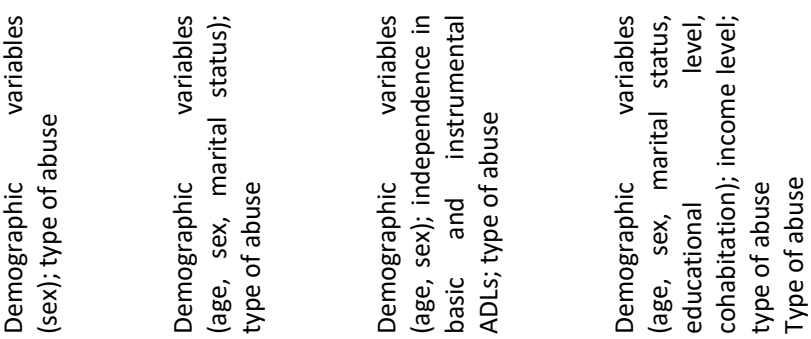

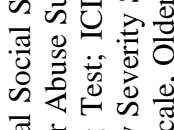

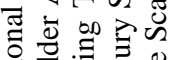

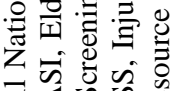

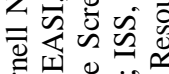

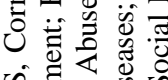
v

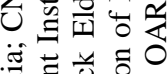

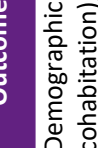

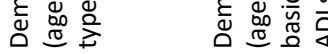

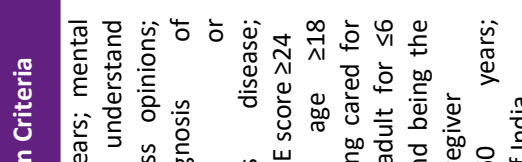

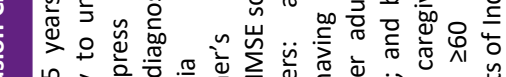

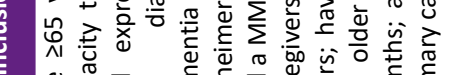

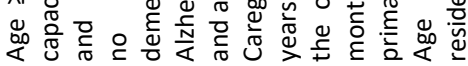

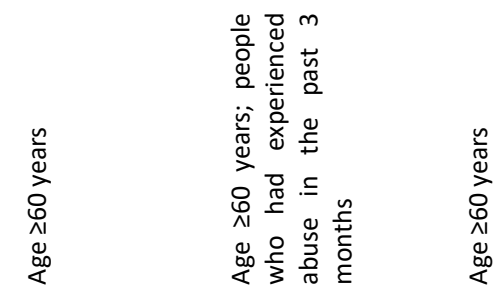

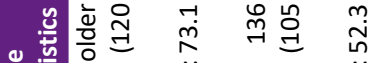

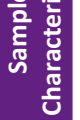

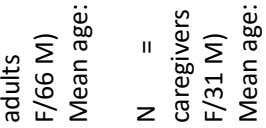

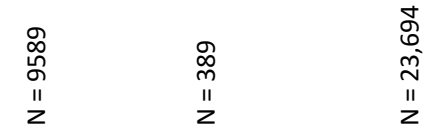

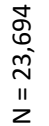

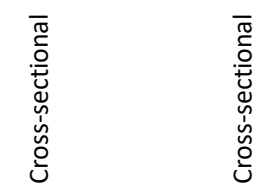

$\vec{\infty}$
$\stackrel{0}{\prime \prime}$
$z$

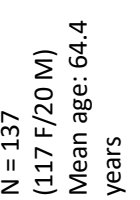

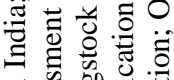

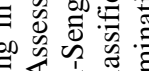
要通

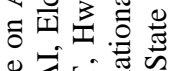

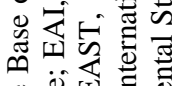

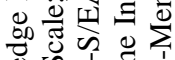

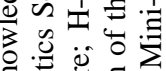
记 on

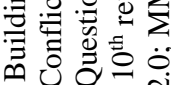
a 0 i

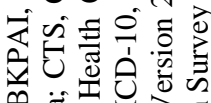
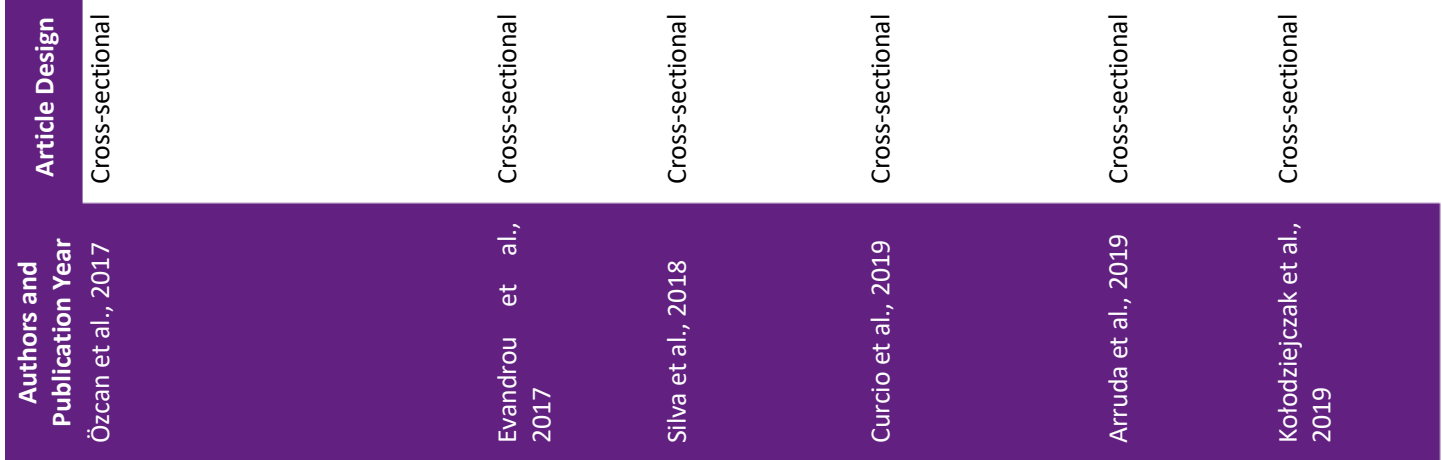

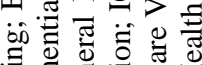

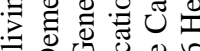

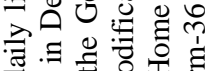
해욜 पั口

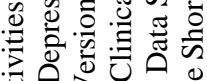

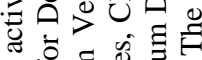

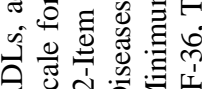


Silva et al., 2012; Chan et al., 2013; Martins-Gil et al., 2014; Park, 2014; Reis et al., 2014; Skirbekk and James, 2014; Wilson et al., 2014; Edirisinghe et al., 2014; Gil et al., 2015; Smith, 2015; Tareque et al., 2015; Carmona-Torres et al., 2015; de Paiva and Tavares, 2015; Morowatisharifabad et al., 2016; Sepúlveda-Carrillo et al., 2016; Farid, 2017; Leung et al., 2017; Lino et al., 2017; Özcan et al., 2017; Silva et al., 2018; Kołodziejczak et al., 2019; Arruda et al., 2019; Curcio et al., 2019) and 9 showing fair methodological quality (2/3 stars) (Heath et al., 2005; Manthorpe et al., 2007; Sánchez-Salgado, 2007; Gaiolo and Rodrigues, 2008; Biggs et al., 2009; Acierno et al., 2010; Alizadeh-Khoei et al., 2014; Evandrou et al., 2017; Breckman et al., 2018). The case-control study had good methodological quality (6/9 stars) (Friedman et al., 2011). The intervention of a third evaluator was required to reach consensus on the quality of two articles (Gaiolo and Rodrigues, 2008; Friedman et al., 2011). The agreement between the two evaluators, according to the kappa coefficient, was high $(\kappa=0.757)$. Tables 2 and 3 show the numerical results of the NOS scale.

\section{Qualitative analysis}

The following section presents the results of the qualitative analysis of the studies' results according to their level of evidence.

There is limited evidence showing that women are more frequently abused than men (Ruiz Sanmartín et al., 2001; Kuniyoshi et al., 2003; Gaiolo and Rodrigues, 2008; Friedman et al., 2011; Ghodousi et al., 2011; Kissal and Beşer, 2011; Amstadter et al., 2011; Abdel Rahman and El Gaafary, 2012; Chan et al., 2013; Alizadeh-Khoei et al., 2014; Skirbekk and James, 2014; Edirisinghe et al., 2014; Gil et al., 2015; Tareque et al., 2015; Carmona-Torres et al., 2015; de Paiva and Tavares, 2015; Sepúlveda-Carrillo et al., 2016; Evandrou et al., 2017; Leung et al., 2017; Lino et al., 2017; Özcan et al., 2017; Silva et al., 2018; Breckman et al., 2018; Arruda et al., 2019; Curcio et al., 2019). This variable was assessed using multiple tools: interviews (Ruiz Sanmartín et al., 2001; Alizadeh-Khoei et al., 2014; de Paiva and Tavares, 2015; Evandrou et al., 2017; Lino et al., 2017; Breckman et al., 2018; Arruda et al., 2019) [semistructured (Alizadeh-Khoei et al., 2014) and by telephone (Breckman et al., 2018)], questionnaires (Kuniyoshi et al., 2003; Amstadter et al., 2011; Friedman et al., 2011; Ghodousi et al., 2011; Kissal and Beşer, 2011; Abdel Rahman and El Gaafary, 2012; Skirbekk and James, 2014; Edirisinghe et al., 2014; Tareque et al., 2015; Carmona-Torres et al., 2015; Gil et al., 2015; Sepúlveda-Carrillo et al., 2016; Leung et al., 2017; Özcan et al., 2017; Curcio et al., 2019), an arbitral award (Gaiolo and Rodrigues, 2008), a clinical report/self-report (Chan et al., 2013) and a computer script (Silva et al., 2018).

There is conflicting evidence indicating that a low educational level is a risk factor for abuse (Shimbo et al., 2011; Abdel Rahman and El Gaafary, 2012; Martins-Gil et al., 2014; Skirbekk and James, 2014; Smith, 2015; Carmona-Torres et al., 2015; de Paiva and Tavares, 2015; Gil et al., 2015; Özcan et al., 2017; Breckman et al., 2018; Kołodziejczak et al., 2019), whether it is the educational level of the older adult or the caregiver. A number of studies did not link a low educational level with a greater probability of abuse (Kuniyoshi et al., 2003; Biggs et al., 2009; Lino et al., 2017). This variable was evaluated through interviews (Kuniyoshi et al., 2003; Friedman et al., 2011; Gil et al., 2015), a telephone interview (Lino et al., 2017), a semi-structured interview (Martins-Gil et al., 2014), questionnaires (Biggs et al., 2009; Shimbo et al., 2011; Abdel Rahman and El Gaafary, 2012; Skirbekk and James, 2014; Carmona-Torres et al., 2015; de Paiva and Tavares, 2015; Smith, 2015; Özcan et al., 2017; Breckman et al., 2018) [demographic (Breckman et al., 2018)].

There is limited evidence that income level is related to abuse (Sánchez-Salgado, 2007; Ghodousi et al., 2011; Almeida-da-Silva et al., 2012; AlizadehKhoei et al., 2014; Gil et al., 2015; Tareque et al., 2015; Arruda et al., 2019). Specifically, a low socioeconomic status is related to a higher probability of abuse. This variable was evaluated through an interview (Arruda et al., 2019), a semi-structured interview (Alizadeh-Khoei et al., 2014), questionnaires (Ghodousi et al., 2011; Almeida-da-Silva et al., 2012; Gil et al., 2015; Tareque et al., 2015) and a data collection form (Sánchez-Salgado, 2007).

There is limited evidence that functional dependence might be related to the probability of experiencing some type of abuse (Ruiz Sanmartín et 


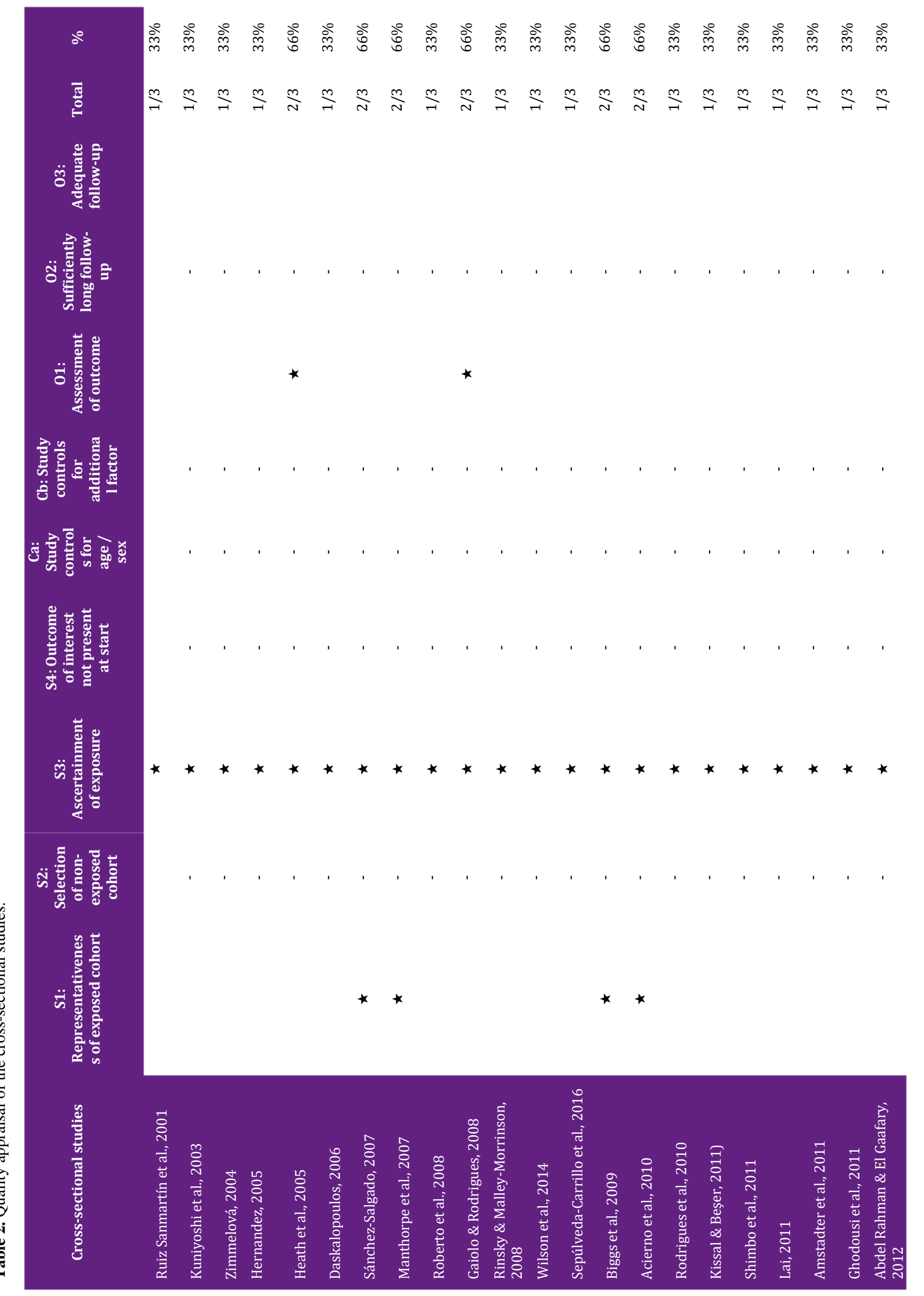




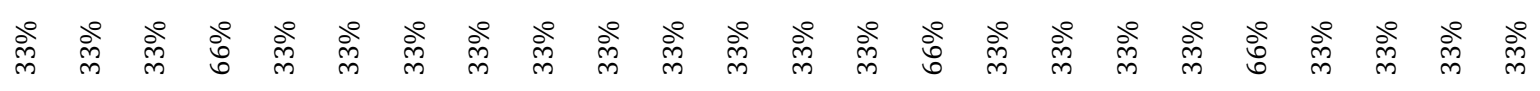

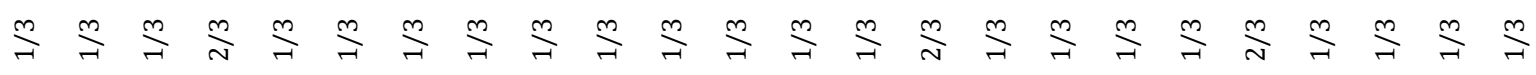

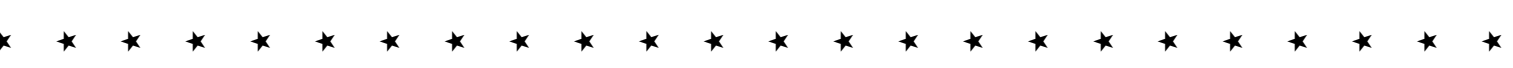

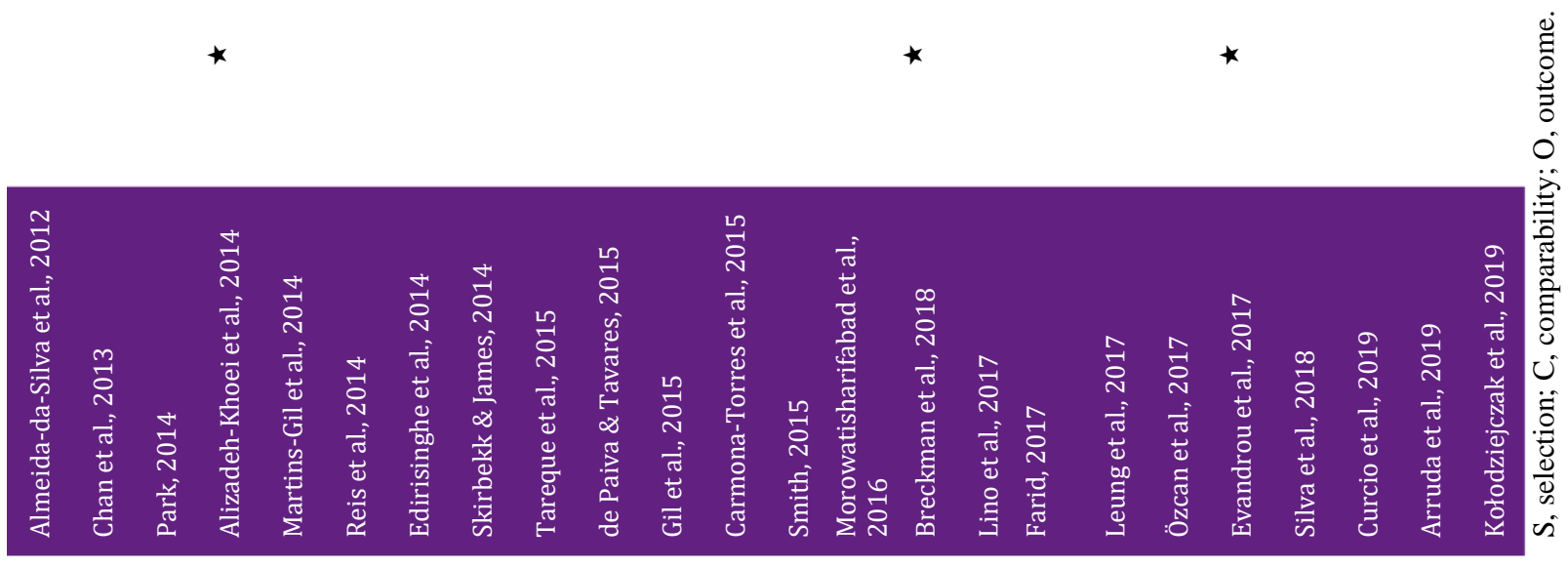


el Gaafary, 2012; de Paiva and Tavares, 2015; Lino et al., 2017; Curcio et al., 2019). Functional independence was assessed using the Katz Index (Ruiz Sanmartín et al., 2001; Kissal and Beşer, 2011; Abdel Rahman and El Gaafary, 2012; de Paiva and Tavares, 2015; Lino et al., 2017), the Barthel Index (Curcio et al., 2019) and the Lawton Instrumental Activities of Daily Living Scale (de Paiva and Tavares, 2015; Curcio et al., 2019).

There is limited evidence that the presence of cognitive impairment in older adults is related to abuse (Heath et al., 2005; Leung et al., 2017; Lino et al., 2017). This variable was assessed using the MiniMental State Examination scale (Heath et al., 2005; Lino et al., 2017) and the Cognitive Performance Scale (Leung et al., 2017).

There is limited evidence showing that in most cases of abuse there is a first-degree relationship (spouse, children) between the victim and the abuser (Ruiz Sanmartín et al., 2001; Kuniyoshi et al., 2003; Zimmelová, 2004; Sánchez-Salgado, 2007; Gaiolo and Rodrigues, 2008; Friedman et al., 2011; Lai, 2011; Gil et al., 2015; Smith, 2015; Sepúlveda-Carrillo et al., 2016). To a lesser extent, there is a second-degree relationship (son-in-law, daughter-in-law, grandchildren) between victim and abuser (Abdel Rahman and El Gaafary, 2012). This variable was evaluated through interviews (Ruiz Sanmartín et al., 2001; Smith, 2015), questionnaires (Kuniyoshi et al., 2003; Zimmelová, 2004; Friedman et al., 2011; Lai, 2011; Abdel Rahman and El Gaafary, 2012; Gil et al., 2015; Sepúlveda-Carrillo et al., 2016), a data collection form (Sánchez-Salgado, 2007) and an arbitral award (Gaiolo and Rodrigues, 2008).

There is limited evidence suggesting a greater likelihood of abuse if the victim or caregiver has depression or anxiety (Heath et al., 2005; Lino et al., 2017; Breckman et al., 2018). This variable was assessed with the Geriatric Depression Scale (Heath et al., 2005; Lino et al., 2017) and a telephone interview (Breckman et al., 2018).

There is limited evidence that substance use by caregivers is associated with an increased likelihood of abuse (Friedman et al., 2011; Ghodousi et al., 2011; Lino et al., 2017). This variable was measured with the CAGE questionnaire (Friedman et al., 2011; Lino et al., 2017) and a custom questionnaire (Ghodousi et al., 2011).

There is limited evidence on the existing typology of abuse (Abdel Rahman \& El Gaafary, 2012; Acierno et al., 2010; Alizadeh-Khoei et al., 2014; Amstadter et al., 2011; Arruda et al., 2019; Biggs et al., 2009; Carmona-Torres et al., 2015; Chan et al., 2013; Curcio et al., 2019; Daskalopoulos, 2006; de Paiva \& Tavares, 2015; Edirisinghe et al., 2014; Evandrou et al., 2017; Farid, 2017; Friedman et al., 2011; Ghodousi et al., 2011; Gil et al., 2015; Heath et al., 2005; Hernandez, 2005; Kissal \& Beşer, 2011; Kołodziejczak et al., 2019; Kuniyoshi et al., 2003; Lai, 2011; Manthorpe et al., 2007; Martins-Gil et al., 2014; Morowatisharifabad et al., 2016; Özcan et al., 2017; Park, 2014; Reis et al., 2014; Rinsky \& Malley-Morrinson, 2008; Roberto et al., 2008; Rodrigues et al., 2010; Ruiz Sanmartín et al., 2001; Sánchez-Salgado, 2007; Sepzúlveda-Carrillo et al., 2016; Shimbo et al., 2011; Silva et al., 2018; Skirbekk \& James, 2014; Tareque et al., 2015; Wilson et al., 2014; Zimmelová, 2004), with the most prevalent type of abuse being psychological abuse (Ruiz Sanmartín et al., 2001; Kuniyoshi et al., 2003; Zimmelová, 2004; Hernández-Ramírez, 2005; Daskalopoulos, 2006; Rinsky and Malley-Morrinson, 2008; Acierno et al., 2010; Rodrigues et al., 2010; Friedman et al., 2011; Ghodousi et al., 2011; Kissal and Beşer, 2011; Lai, 2011; Amstadter et al., 2011; Chan et al., 2013; Alizadeh-Khoei et al., 2014; Martins-Gil et al., 2014; Reis et al., 2014; Skirbekk and James, 2014; Wilson et al., 2014; Edirisinghe et al., 2014; Gil et al., 2015; Carmona-Torres et al., 2015; de Paiva and Tavares, 2015; Sepúlveda-Carrillo et al., 2016; Evandrou et al., 2017; Farid, 2017; Özcan et al., 2017; Kołodziejczak et al., 2019; Arruda et al., 2019; Curcio et al., 2019). This variable was measured using questionnaires (Kuniyoshi et al., 2003; Zimmelová, 2004; Hernández-Ramírez, 2005; Daskalopoulos, 2006; Rinsky and Malley-Morrinson, 2008; Friedman et al., 2011; Ghodousi et al., 2011; Kissal and Beşer, 2011; Lai, 2011; Park, 2014; Skirbekk and James, 2014; Wilson et al., 2014; Tareque et al., 2015; Gil et al., 2015; Sepúlveda-Carrillo et al., 2016; Morowatisharifabad et al., 2016; Özcan et al., 2017; Curcio et al., 2019), interviews (Ruiz Sanmartín et al., 2001; Manthorpe et al., 2007; Biggs et al., 2009; Acierno et al., 2010; Rodrigues et al., 2010; Shimbo et al., 2011; Martins-Gil et al., 2014; Park, 2014; Reis et 
al., 2014; Farid, 2017), data collection forms (SánchezSalgado, 2007; Roberto et al., 2008), the Elder Assessment Instrument (Abdel Rahman and El Gaafary, 2012), a clinical report/self-report (Chan et al., 2013), the Hwalek-Sengstock Elder Abuse Screening Test (Alizadeh-Khoei et al., 2014; Edirisinghe et al., 2014), the Conflict Tactics Scale (de Paiva and Tavares, 2015; Arruda et al., 2019), the Elder Abuse Suspicion Index (Carmona-Torres et al., 2015), the General Health Questionnaire-12 (Evandrou et al., 2017) and a computer script (Silva et al., 2018).

\section{DISCUSSION}

This systematic review aimed to identify the variables associated with the abuse of older adults and found numerous factors that appear to affect the abuse of older adults in their home environment. These variables can be divided in two major groups: personal and caregiver-related.

Being female appears to be related to the risk of experiencing both physical and mental abuse. In many cases, the assumption of traditional roles, such as submission to their husband, taking care of the children, the silent acceptance of problems, the need to maintain privacy over family dynamics and the loss of roles in the home due to disability appear to be reasons related to this variable (Aronson et al., 1995; Seaver, 1996; Wolf, 1997, 2000; Hightower et al., 2001; Straka and Montminy, 2006).

A low level of education and income predisposes older adults to requiring care from others. In many cases, this role is fulfilled by informal caregivers, such as family members and friends (Gordon and Brill, 2001; Strasser et al., 2011). Educational level is a determining factor in an individual's position in the labor market. Workers with a higher educational level have access to better paying jobs and greater economic stability. Individuals who retire from poorly paid jobs experience an increased loss of income that puts them in a situation of greater dependence on those they live with. In general, women receive lower pensions than men. In Spain, a gender gap in wages of $34.46 \%$ has been reported, which is below the minimum interprofessional wage and worsens after widowhood (Strasser et al., 2011; epdata, 2020b, 2020a).

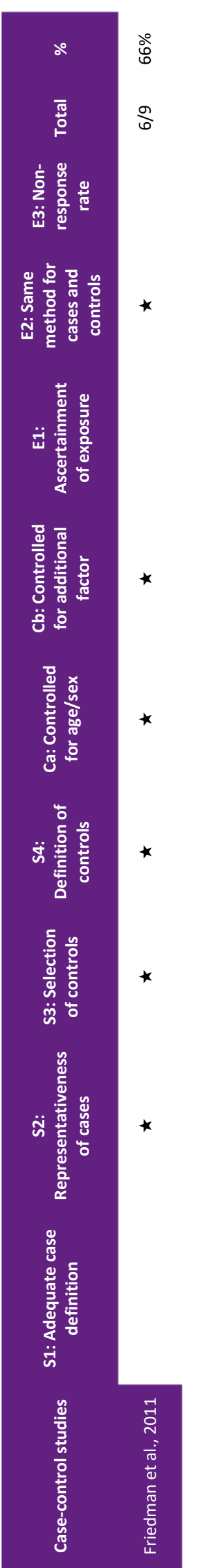


The caregiver-related variables identified in the studies are consanguinity, mood disorders and substance abuse. A number of authors have already found an association between mental health problems and abuse committed against older adults, determining a relationship between mental health problems and alcohol and drug abuse, especially when the caregiver is a family member (Wolf, 1994; Hwalek et al., 1996; Caballero García and Remolar, 2000). This situation could be related to burnout, which has been widely studied in health professionals (Ortega Ruiz and López Ríos, 2004) but whose characteristics can also be applied to informal caregivers. These caregivers decrease their sensitivity and understanding toward the people they care for and hold them accountable for their emotional overload and stress to the extent that they sometimes resort to violence (Calero Pérez et al., 2009; Marchena Hernández and Torres Brieva, 2011). In many cases, it is difficult to reconcile a family and work life that generates conflicts (Otálora Montenegro, 2007).

Regarding the types of abuse, there were no differences in relation to other studies in which physical and verbal abuse and neglect stood out as the main forms of abuse (Chintanawat, 2003; PérezCárceles et al., 2009; Giraldo Rodríguez, 2010; Bigala and Ayiga, 2014). It seems clear that, despite the passage of time, the characteristics of older adults who experience abuse and the characteristics of caregivers who mistreat them remain unchanged. The stability of the factors related to abuse can be employed as a solid basis for designing prevention policies and community action programs that help reduce the incidence and prevalence of abuse in the elderly population.

\section{Limitations}

Most of the studies have a high risk of bias due to their methodological quality and limited sample sizes, which might affect the results. In addition, heterogeneity in the included studies regarding the sample's characteristics, and the outcome and assessment measures have prevented the realization of a quantitative analysis.

\section{CONCLUSION}

The results of the present systematic review showed that there are numerous risk factors that increase the likelihood of abuse in older adults. Psychological abuse was identified as the most common type of abuse. The term "abuse" is widely associated with situations of physical violence, which is why psychological abuse often goes completely unnoticed.

\section{HIGHLIGHTS}

$>$ Personal and caregiver-related factors affect the abuse of older adults in their home environment.

$>$ Females with a low income and cognitive or functional impairment are at a greater risk of being abused.

$>$ Caregivers' consanguinity, mood disorders, and substance abuse increase the likelihood of abuse.

\section{Acknowledgements}

The authors would like to thank Centro Superior de Estudios Universitarios CSEU La Salle for its services in editing this manuscript.

\section{REFERENCES}

Abdel Rahman TT, El Gaafary MM. Elder mistreatment in a rural area in Egypt. Geriatr Gerontol Int. 2012;12(3):532-7 DOI: http://dx.doi.org/10.1111/j.1447-0594.2011.00780.x.

Acierno R, Hernandez MA, Amstadter AB, Resnick HS, Steve K, Muzzy W, Kilpatrick DG. Prevalence and correlates of emotional, physical, sexual, and financial abuse and potential neglect in the United States: The national elder mistreatment study. Am J Public Health. 2010;100(2):292-7 DOI: http://dx.doi.org/10.2105/AJPH.2009.163089.

Alizadeh-Khoei M, Sharifi F, Hossain SZ, Fakhrzadeh H, Salimi Z. Elder abuse: risk factors of abuse in elderly communitydwelling iranians. Educ Gerontol. 2014;40(7):543-54 DOI: http://dx.doi.org/10.1080/03601277.2013.857995.

Almeida-da-Silva V, Costa-Ramos J, Queiroz F, Bezerra-doAmaral F, Souza-de-Oliveira C, Menezes M. Violência doméstica contra idosos: agressões praticadas por pessoas 
com sofrimento mental. Rev Eletrônica Enferm. 2012;14(3):523-31

DOI:

http://dx.doi.org/10.5216/ree.v14i3.12953.

Amstadter AB, Zajac K, Strachan M, Hernandez MA, Kilpatrick DG, Acierno R. Prevalence and correlates of elder mistreatment in South Carolina: The South Carolina elder mistreatment study. J Interpers Violence. 2011;26(15):294772 DOI: http://dx.doi.org/10.1177/0886260510390959.

Aronson J, Thornewell C, Williams K. Wife Assault in Old Age: Coming out of Obscurity. 1995;14:72-88.

Arruda L, Aparecida F, Fiori G, Cândida N, Anibal F, Mara dos Santos D. Violência contra idosos: preditores e distribuição espacial. Ciência, Cuid e Saúde. 2019;18(1):1-9 DOI: http://dx.doi.org/10.4025/cienccuidsaude.v18i1.45043.

Bazo MT. Negligencia y malos tratos a las personas mayores en españa. Rev Esp Geriatr Gerontol. 2001;36(1):8-14 DOI: http://dx.doi.org/10.1016/s0211-139x(01)74673-2.

Beard J, Ferguson L, Marmot M. Informe mundial sobre envejecimiento y salud. Organ Mund la Salud. 2015;1-282.

Bigala P, Ayiga N. Prevalence and predictors of elder abuse in mafikeng local municipality in South Africa. Etude la Popul Africaine. 2014;28(1):463-74 DOI: http://dx.doi.org/10.11564/28-1-500.

Biggs S, Manthorpe J, Tinker A, Doyle M, Erens B. Mistreatment of older people in the united kingdom: Findings from the first national prevalence study. J Elder Abus Negl. 2009;21(1):114 DOI: http://dx.doi.org/10.1080/08946560802571870.

Breckman R, Burnes D, Ross S, Marshall P, Suitor J, Lachs M, Pillener K. When helping hurts: nonabusing family, friends, and neighbors in the lives of elder mistreatment victims. Gerontologist. 2018;58(4):719-23 DOI: http://dx.doi.org/10.1093/geront/gnw257.

Caballero García JC, Remolar M. Consideraciones sobre el maltrato al anciano. Rev Multidiscip Gerontol. 2000;10(3):177-88.

Calero Pérez RM, Fernández Prados C, Venegas Roa JM. Cuidador informal de personas mayores dependientes y estrés percibido: intervención psicoeducativa. Scientia. 2009;14:919.

Carmona-Torres JM, López-Soto PJ, Coimbra-Roca AI, GálvezRioja RM, Goergen T, Rodríguez-Borrego MA. Elder Abuse in a Developing Area in Bolivia. J Interpers Violence. 2015;33(2):339-56

DOI: http://dx.doi.org/10.1177/0886260515608803.

Chan KL, Choi AWM, Fong DYT, Chow CB, Leung M, Ip P. Characteristics of family violence victims presenting to emergency departments in Hong Kong. J Emerg Med. Elsevier Ltd; 2013;44(1):249-58 DOI: http://dx.doi.org/10.1016/j.jemermed.2012.01.061.

Chintanawat R. Prevalence and risk factors for abuse among Thai older adults in Chiang Mai. Chiang Mai Univ. 2003.

Cohen J. A coefficient of agreement for nominal scale. Educ Psychol Meas. 1960;20(1):37-46.

Curcio CL, Payán-Villamizar C, Jiménez A, Gómez F. Abuse in Colombian elderly and its association with socioeconomic conditions and functionality. Colomb Medica.
2019;50(2):77-88

DOI:

http://dx.doi.org/10.25100/cm.v50i2.4013.

Daskalopoulos M. English Perceptions of Elder Abuse. J Elder Abus Negl. 2006;8(2-3):33-50 DOI: http://dx.doi.org/10.1300/J084v18n02.

Deeks J, Dinnes J, D’Amico R, Sowden A, Sakarovitch C, Song F, Al. E. Evaluating non-randomised intervention studies. Heal Technol Assess. 2003;7(27):3-10.

Edirisinghe PAS, Paranitharn P, Perera WNS, Williams SS. Elder abuse among outpatient department attendees in a tertiary care hospital in Sri Lanka. Ceylon Med J. 2014;59(3):84-9 DOI: http://dx.doi.org/10.4038/cmj.v59i3.6527.

epdata. Comparación entre las pensiones medias de viudedad de hombres y mujeres. 2020a;

epdata. Evolución de la pension media entre hombres y mujeres. $2020 \mathrm{~b} ; 12$.

Estrada JDR. El maltrato a las personas mayores: bases teóricas para su estudio. 2008.

Evandrou M, Falkingham JC, Qin M, Vlachantoni A. Elder abuse as a risk factor for psychological distress among older adults in India: A cross-sectional study. BMJ Open. 2017;7(10):119 DOI: http://dx.doi.org/10.1136/bmjopen-2017-017152.

Farid S. Elder abuse and neglect in Bangladesh: Understanding issues, associated factors and consequences. Fam Med Prim Care Rev. 2017;19(2):123-7 DOI: http://dx.doi.org/10.5114/fmpcr.2017.67865.

Fingleton C, Smart K, Moloney N, Fullen BM, Doody C. Pain sensitization in people with knee osteoarthritis: A systematic review and meta-analysis. Osteoarthr Cartil. Elsevier Ltd; 2015;23(7):1043-56 DOI: http://dx.doi.org/10.1016/j.joca.2015.02.163.

Friedman LS, Avila S, Tanouye K, Joseph K. A case-control study of severe physical abuse of older adults. J Am Geriatr Soc. 2011;59(3):417-22 DOI: http://dx.doi.org/10.1111/j.15325415.2010.03313.x.

Gaiolo C, Rodrigues R. Ocurrencia de maltratos a los ancianos en el domicilio. Rev Lat Am Enfermagem. 2008;16(3):465-70 DOI: http://dx.doi.org/10.1590/S0104-11692008000300021.

Generalitat de Catalunya DDASYC. Protocolo de actuación contra el maltrato a las personas mayores. 2007;19 p.

Ghodousi A, Maghsoodloo S, Hoseini SMS. Forensic aspect of elder abuse: Risk factors and characteristics. J Res Med Sci. 2011;16(12):1598-604.

Gil AP, Santos AJ, Kislaya I, Santos C, Mascoli L, Ferreira AI, Vieira DN. Estudo sobre pessoas idosas vítimas de violência em Portugal: Sociografia da ocorrência. Cad Saude Publica. 2015;31(6):1234-46 DOI: http://dx.doi.org/10.1590/0102$311 \mathrm{X} 00084614$.

Giraldo Rodríguez L. El maltrato a personas adultas mayores: una mirada desde la perspectiva de género. Debate Fem. 2010;42(October):151-65 DOI: http://dx.doi.org/10.22201/cieg.2594066xe.2010.42.825.

González RS. Sexo y violencia en los montes de Toledo. 2006.

Gordon RM, Brill D. The abuse and neglect of the elderly. Int J Law Psychiatry. 2001;24(2-3):183-97 DOI: http://dx.doi.org/10.1016/S0160-2527(00)00076-5. 
Heath JM, Kobylarz FA, Brown M, Castaño S. Interventions from home-based geriatric assessments of adult protective service clients suffering elder mistreatment. J Am Geriatr Soc. 2005;53(9):1538-42 DOI: http://dx.doi.org/10.1111/j.15325415.2005.53469.x.

Hernández-Ramírez M. Propuesta de Enfermería para una Vida sin Abuso, Maltrato o Abandono hacia el Adulto. Rev Desarro Científico Enfermería. 2005;13(9):261-6.

Hightower J, Smith MJ (Greta), Hightower H. Silent and invisible: A report on abuse and violence in the lives of older women in British Columbia and Yukon. 2001;604-82.

Hootman JM, Driban JB, Sitler MR, Harris KP, Cattano NM. Reliability and validity of three quality rating instruments for systematic reviews of observational studies. Res Synth Methods. 2011;2(2):110-8 DOI: http://dx.doi.org/10.1002/jrsm.41.

Hwalek MA, Neale AV, Goodrich CS, Quinn K. The association of elder abuse and substance abuse in the Illinois elder abuse system. Gerontologist. 1996;36(5):694-700 DOI: http://dx.doi.org/10.1093/geront/36.5.694.

Kissal A, Beşer A. Elder abuse and neglect in a population offering care by a Primary Health Care Center in Izmir, Turkey. Soc Work Health Care. 2011;50(2):158-75 DOI: http://dx.doi.org/10.1080/00981389.2010.527570.

Kołodziejczak S, Terelak A, Bulsa M. Domestic violence against seniors in rural areas of West Pomerania, Poland. Ann Agric Environ Med. 2019;26(1):92-6 DOI: http://dx.doi.org/10.26444/aaem/92208.

Krug E, Dahlberg L, Mercy J, Zwi A, Lozano R. El maltrato de las personas mayores. Inf Mund Sobre la Violencia y la Salud. 2003;223.

Kuniyoshi M, Horinouchi A, Ryu M, Akamine Y, Maeshiro C, Uza $\mathrm{M}, \mathrm{Al} \mathrm{E}$. Abuse of the elderly living at home in Okinawa: Findings from a survey of home-visiting nurses. 2003;22(34):109-19.

Lai DWL. Abuse and neglect experienced by aging Chinese in Canada. J Elder Abus Negl. 2011;23(4):326-47 DOI: http://dx.doi.org/10.1080/08946566.2011.584047.

Leung DYP, Lo SKL, Leung AYM, Lou VWQ, Chong AML, Kwan JSK, Chan WCH, Chi I. Prevalence and correlates of abuse screening items among community-dwelling Hong Kong Chinese older adults. Geriatr Gerontol Int. 2017;17(1):150-60

DOI: http://dx.doi.org/10.1111/ggi.12655.

Lino VTS, Rodrigues NCP, de Lima IS, Athie S, de Souza ER. Prevalence and factors associated with caregiver abuse of elderly dependents: The hidden face of family violence. Cien Saude Colet. 2017;24(1):87-96 DOI: http://dx.doi.org/10.1590/1413-81232018241.34872016.

Manthorpe J, Biggs S, McCreadie C, Tinker A, Hills A, O'Keefe M, Doyle M, Constantine R, Scholes S, Erens B. The U.K. national study of abuse and neglect among older people. Nurs Older People. 2007;19(8):24-6 DOI: http://dx.doi.org/10.7748/nop2007.10.19.8.24.c6268.

Marchena Hernández J, Torres Brieva D. Población a riesgo de desarrollar síndrome de Burnout y cuales sus factores de riesgo. 2011.

Marmolejo II. Maltrato de personas mayores en la familia en España. Vol. 53, Journal of Chemical Information and Modeling. $\quad$ Valencia; 2008. DOI: http://dx.doi.org/10.1017/CBO9781107415324.004.

Martins-Gil A, Kislaya I, Santos A, Nunes B, Nicolau R, Fernandes A. Elder abuse in Portugal: findings from the first national prevalence study. J Elder Abus Negl. 2014;27(3):174-95 DOI: http://dx.doi.org/10.1080/08946566.2014.953659.

Moher D, Liberati A, Tetzlaff J, Altman DG, Altman D, Antes G, Atkins D, Barbour V, Barrowman N, Berlin JA, Clark J, Clarke M, Cook D, D'Amico R, Deeks JJ, Devereaux PJ, Dickersin K, Egger M, Ernst E, Gøtzsche PC, Grimshaw J, Guyatt G, Higgins J, Ioannidis JPA, Kleijnen J, Lang T, Magrini N, McNamee D, Moja L, Mulrow C, Napoli M, Oxman A, Pham B, Rennie D, Sampson M, Schulz KF, Shekelle PG, Tovey D, Tugwell P. Preferred reporting items for systematic reviews and meta-analyses: The PRISMA statement. PLoS Med. 2009;6(7):e1000097 DOI: http://dx.doi.org/10.1371/journal.pmed.1000097.

Morowatisharifabad MA, Rezaeipandari H, Dehghani A, Zeinali A. Domestic elder abuse in Yazd, Iran: a cross-sectional study. Heal Promot Perspect. 2016;6(2):104-10 DOI: http://dx.doi.org/10.15171/hpp.2016.18.

Moya-Bernal A, Barbero-Gutiérrez J. Malos tratos a personas mayores: guía de actuación. 2005.

Naciones Unidas. Día Mundial de Toma de Conciencia del Abuso y Maltrato en la Vejez. 2020;

Nyamwanza T. Global status report on violence prevention 2014. World Heal Organ. 2014;(June):15.

OMS. Organización Mundial de la Salud. Declaración de Toronto para la Prevención Global del Maltrato de las Personas Mayores. Organ Mund la Salud. 2002;1-4.

OMS. Maltrato de las personas mayores. 2018;

OMS. Maltrato de las personas mayores. 2020.

Organización Panamericana de la Salud. Derechos Humanos y Salud: Personas Mayores. Organ Panam la Salud. 2008;1-12.

Ortega Ruiz C, López Ríos F. El burnout o síndrome de estar quemado en los profesionales sanitarios: revisión y perspectivas. Int J Clin Heal Psychol. 2004;4(1):137-60.

Otálora Montenegro G. La relación existente entre el conflicto trabajo-familia y el estrés individual en dos organizaciones colombianas *. Cuad Adm Bogotá. 2007;20(34):139-60.

Özcan NK, Boyacıŏlu NE, Sertçelik E. Reciprocal abuse: elder neglect and abuse by primary caregivers and caregiver burden and abuse in Turkey. Arch Psychiatr Nurs. 2017;31(2):177-82

DOI: http://dx.doi.org/10.1016/j.apnu.2016.09.011.

de Paiva MM, Tavares DMS. Physical and psychological violence against the elderly: prevalence and associated factors. Rev Bras Enferm. 2015;68(6):1035-41 DOI: http://dx.doi.org/10.1590/0034-7167.2015680606i.

Park HJ. Living with "Hwa-byung": The psycho-social impact of elder mistreatment on the health and well-being of older people. Aging Ment Heal. Taylor \& Francis; 2014;18(1):1258 DOI: http://dx.doi.org/10.1080/13607863.2013.814103. 
Pérez-Cárceles MD, Rubio L, Pereniguez JE, Pérez-Flores D, Osuna E, Luna A. Suspicion of elder abuse in South Eastern Spain: The extent and risk factors. Arch Gerontol Geriatr. 2009;49(1):132-7

DOI: http://dx.doi.org/10.1016/j.archger.2008.06.002.

Pérez-Díaz J, Abellán-García A, Aceituno-Nieto P, Ramiro-Fariñas D. Un perfil de las personas mayores en España 2020. 2020;1-39.

Quirós E. El impacto de la violencia intrafamiliar: transitando de la desesperanza a la recuperación del derecho a vivir libres de violencia. Perspect psicológicas. 2003;3-4:155-63.

Reis L, Gomes N, Reis L, Menezes T, Carneiro J. Expression of domestic violence against older people Expressão da violência intrafamiliar contra idosos. Acta Paul Enferm. 2014;27(5):434-9 DOI: http://dx.doi.org/10.1590/19820194201400072.

Rinsky K, Malley-Morrinson K. Russian perspectives on elder abuse: an exploratory study. J Elder Abuse Negl. 2008;18(23):123-39 DOI: http://dx.doi.org/10.1300/J084v18n02.

Roberto K, Teaster P, Duke J. Older women who experience mistreatment: circumstances and outcomes. J Women Aging. 2008;79(2):76-9 DOI: http://dx.doi.org/10.1300/J074v16n01.

Rodrigues TP, Moreira MASP, Silva AO, Smith AAF, Almeida JLT de, Lopes MJ. Sentidos associados à violência para idosos e profissionais. Esc Anna Nery. 2010;14(4):772-8 DOI: http://dx.doi.org/10.1590/s1414-81452010000400017.

Ruiz Sanmartín A, Altet Torner J, Porta Martí N, Duaso Izquierdo P, Coma Solé M, Requesens Torrellas N. Domestic violence: prevalence of suspected ill treatment of the elderly. Aten Primaria. Elsevier; 2001;27(5):331-4 DOI: http://dx.doi.org/10.1016/S0212-6567(01)79376-6.

Saavedra J, Murvartian L, Vallecillo N. Salud y burnout de cuidadores profesionales a domicilio: Impacto de una intervención formativa. Anal Psicol. 2020;36(1):30-8.

Sánchez-Salgado CD. Características del abuso y maltrato de personas ancianas en Puerto Rico. PRHSJ. 2007;26(1):35-41.

Seaver C. Muted lives: Older battered women. Journal of Elder Abuse \& Neglect. J Elder Abus Negl. 1996;8(2):3-21 DOI: http://dx.doi.org/10.1300/J084v08n02.

Segura S. ¿Por qué una convención para la protección de los derechos a de las personas adultas mayores? Rev Firma. 2016;10:52-3.

Sepúlveda-Carrillo G, Arias-Portela J, Cuervo-Rojas A, GutiérrezGómez S, Olivos-Álvarez S, Rincón-Hernández M, Al E. Caracterización de los casos de maltrato en el adulto mayor denunciados en la Comisaría Primaria de Familia en la Localidad de Usaquén en el año 2007. Rev Colomb Enfermería. 2016;4(4):51-60 DOI: http://dx.doi.org/10.18270/rce.v4i4.1411.

Shimbo AY, Labronici LM, Mantovani M de F. Reconhecimento da violência intrafamiliar contra idosos pela equipe da estratégia saúde da família. Esc Anna Nery. 2011;15(3):50610 DOI: http://dx.doi.org/10.1590/s141481452011000300009.

Silva GCN, Almeida VL, de Brito TRP, Godinho MLS da C, Nogueira DA, Chini LT. Violence against elderly people: A documentary analysis. Aquichan. 2018;18(4):449-60 DOI: http://dx.doi.org/10.5294/aqui.2018.18.4.7.

Skirbekk V, James KS. Abuse against elderly in India - The role of education. BMC Public Health. 2014;14(1):1-8 DOI: http://dx.doi.org/10.1186/1471-2458-14-336.

Smith JR. Expanding constructions of elder abuse and neglect: older mothers' subjective experiences. J Elder Abus Negl. 2015;27(4-5):328-55

DOI: http://dx.doi.org/10.1080/08946566.2015.1082527.

Straka SM, Montminy L. Responding to the needs of older women experiencing domestic violence. Violence Against Women. 2006;12(3):251-67

DOI: http://dx.doi.org/10.1177/1077801206286221.

Strasser SM, Kerr J, King PS, Payne B, Beddington S, Pendrick D, Leyda E, McCarty F. A survey of georgia adult protective service staff: Implications for older adult injury prevention and policy. West J Emerg Med. 2011;12(3):357-64.

Tareque MI, Islam TM, Koshio A, Kawahara K. Economic wellbeing and elder abuse in Rajshahi district of Bangladesh. Res Aging. 2015;37(2):200-24 DOI: http://dx.doi.org/10.1177/0164027514527833.

Tortosa JM. Personas mayores y malos tratos. Ediciones Pirámide. 2004;1:41-59.

van Tulder M, Furlan A, Bombardier C, Bouter L. Updated Method Guidelines for Systematic Reviews in the Cochrane Collaboration Back Review Group. Spine (Phila Pa 1976). Ovid Technologies (Wolters Kluwer Health); 2003;28(12):1290-9 DOI: http://dx.doi.org/10.1097/01.brs.0000065484.95996.af.

Wells G, Shea B, O'Connel D, Peterson J, Welch J, Losos M, Tugwell P. The Newcastle-Ottawa Scale (NOS) for assessing the quality of nonrandomized studies in meta-analysis [manuals and scales]. Ottawa Heal Res Inst Ottawa, ON, Cananda, 2015. 2008;

Wilson LB, Simson S, McCaughey K. The status of preventive care for the aged: A meta-analysis. Aging Prev New Approaches Prev Heal Ment Heal Probl Older Adults. 2014;3(1):23-38 DOI: http://dx.doi.org/10.4324/9781315826387.

Wolf RS. El problema de los abusos a los ancianos: una tragedia familiar. Rev Gerontol. 1994;4(2):134-8.

Wolf RS. Elder abuse and neglect: An update. Rev Clin Gerontol. 1997;7(2):177-82 DOI: http://dx.doi.org/10.1017/S0959259897000191.

Wolf RS. The Older Battered Woman. Inst Aging, Univ Massachusetts, Meml Heal Care Concern. 2000;1-5.

Zimmelová P. Domestic violence and seniors. Ryukyu Med J. 2004;59-66. 
Appendix 1. Search strategies

\begin{tabular}{|c|c|}
\hline Databases & Strategies \\
\hline SciELO & ((((elderly) AND abuse) AND aged) AND neglect) and family and not child \\
\hline CINAHL & ((((elderly) AND abuse) AND aged) AND neglect) and family \\
\hline CUIDEN & ("maltrato") AND (“anciano") \\
\hline Cochrane & (elderly) AND abuse) AND aged) AND neglect) and family and not child \\
\hline PubMed & 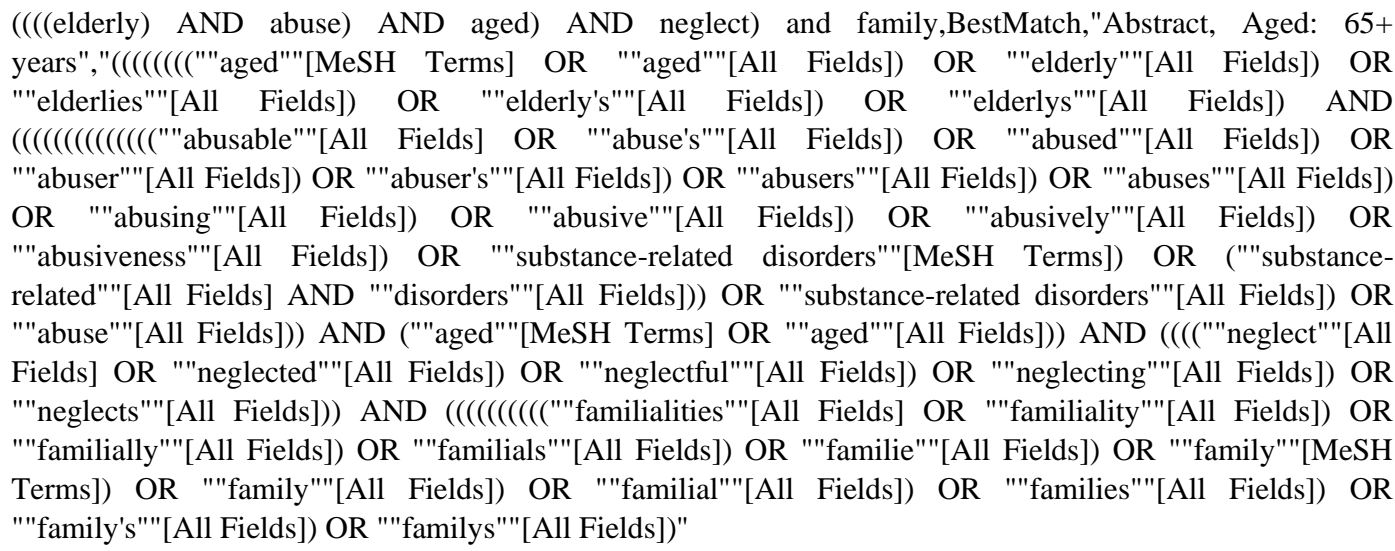 \\
\hline Google Scholar & $\begin{array}{l}\text { elderly AND abuse AND aged AND neglect and family and article journal -"systematic review" -review - } \\
\text { book -hospital -community -childhood -adolescent }\end{array}$ \\
\hline
\end{tabular}

